\begin{tabular}{llllllllllllllllllllllllllll}
\hline A & C & T & A & A & R & C & H & A & E & O & L & O & G & I & C & A & C & A & R & P & A & T & H & I & C & A
\end{tabular}

\begin{tabular}{lr} 
VOL. LV (2020): 137-196 & PL ISSN 0001-5229 \\
\hline
\end{tabular}

DOI 10.4467/00015229AAC.20.007.13512

\author{
BARBARA NiEZABITOWSKA-WiŚNIEWSKA ${ }^{(10)}$
}

\title{
Circular weights in Przeworsk culture - FISHNET SINKERS OR ELEMENTS OF A LOOMS. AN ATTEMPT OF INTERPRETATION
}

\begin{abstract}
Clay circular weights are most often interpreted as sinkers for fishing nets or weaving weights - an elements of the vertical warp-weighted looms. The starting point for writing this article was the presence of such specimens at four settlements of the Przeworsk culture located on the right side of the Vistula River (Dobre, Nieszawa Kolonia, Oronne, Puławy-Włostowice). The oldest circular weights are dated back to the Neolithic period. With varying intensity, they are also recorded within the sites of all subsequent periods and in various parts of Europe. The youngest are related to the Middle Ages and Modern Age. The article focuses mainly on circular weights from the Roman Period and the early phase of the Migration Period (Przeworsk culture, Wielbark culture, Masłomęcz group, Luboszyce culture / Elbe circle), also using chronologically and culturally different analogies, as well as the results of experimental archaeology, iconographic and ethnographic sources. Circular weights were analysed for the possibility of relating them with weaving and / or fishing. In the first case, I focus on the analysis of factors such as: the context of the discovery, the number and condition of the weights, as well as their shape, weight and the presence of use-wear traces. In the second, issues such as raw material, accuracy and method of production, as well as weight, place and context of discovery, accompanying artefacts were considered.
\end{abstract}

Keywords: European Barbaricum, Roman and Migration Periods, Przeworsk culture, circular weights, weaving, loom, fishing, sinkers, experimental archaeology, ethnographic sources

\section{INTRODUCTION}

Weaving and fishing during the Roman Period and in the early phase of the Migration Period for years have attracted the attention of numerous researchers, not only archaeologists. While weaving is relatively well recognized, fishing is one of the least known branches of the food economy of the Central European Barbaricum population, including the Przeworsk culture. Considering the fact, that the settlements were usually located near watercourses, it can be assumed

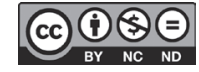


that the fish were included into edibles, supplementing the daily diet of the Przeworsk culture community ( $c f$. Wielowiejski 1960, 165; Makowiecki 2003, 103-105; Rodzińska-Nowak 2012, 122-123; Stasiak-Cyran 2018, 48-49). The insufficiency of the archaeological sources that could allow the reconstruction of the species diversity of consumed fish and/or molluscs or fishing methods, may be related to the post-depositional factors, as a result of which the fragile remains of these animals, as well as tools used to their harvesting, made of organic materials, have been completely decomposed. In the face of the dominance of the cremation funeral rite, the chance of the fish remains preservation in the graves is even lesser. The difficulties in interpreting of the purpose of some artefacts discovered in the Przeworsk culture settlements are also significant, and thus the undisputed linking them with fishing is impossible. Group of these artefacts included the somewhat round, clay weights with a centrally located hole, interpreted as loom weights or as sinkers for loading the fishnet.

The current literature lacks of standardized terminology for this category of artefacts - regardless of the assigned function. They are described as discoidal, oval, round, circular, cylindrical or - slightly more often - flat-spherical weights. In the typology of loom weights recently proposed by J. Słomska - designed as universal, with the possibility of using for all artefacts in this category, regardless of the prehistory period - these artefacts are included in type II (Słomska 2019, 93, fig. 1, pl. 1: D). Differences in the cross-section shapes of these specimens, although sometimes insignificant, in my opinion exclude the term "flat-spherical", so far most commonly used in relation to these artefacts, as universal. Therefore, taking into account their general shape, in this article I will use the term "circular weights".

\section{CIRCULAR WEIGHTS FROM THE "VISTULA RIVER" PRZEWORSK CULTURE SETTLEMENTS}

Undertaking of the subject of circular weights ${ }^{1}$ interpretation is related to the discovery of such specimens at four settlement sites of the Przeworsk culture in: Dobre, Opole Lubelskie District (site 2); Nieszawa Kolonia, Opole Lubelskie District (site 5); Oronne, Garwolin District (site 1) and Puławy-Włostowice, Puławy District (site 3). Mentioned sites are positioned at relatively close distance to each other. Moreover, all of them are located in the Vistula region, mostly in the valleys of Vistula's small tributaries: settlement in Dobre - on the summit and the southern slope of the elevation located within the bottom terrace of the Chodelka river valley, about $2.5 \mathrm{~km}$ from the Vistula riverbed as the crow flies;

${ }^{1}$ In the descriptions I will consciously use the main name of the analysed category of artefacts weights, without the terms "loom" or "fishnet", which clearly suggest their function. 
settlement in Nieszawa Kolonia - in the valley of the Wyżnianka river, about 1.5 $\mathrm{km}$ from the modern Vistula riverbed; settlement in Oronne - on a dune within wet meadows between the Okrzejka and Pytlocha rivers, in direct line about 10 $\mathrm{km}$ from the Vistula riverbed; settlement in Puławy-Włostowice - at the bottom of the Vistula valley ${ }^{2}$, about $1.5 \mathrm{~km}$ from its modern riverbed. In this article I will call them "Vistula" sites of Przeworsk culture (Fig. 1).

Within the settlement in Dobre, three complete weights and 13 fragments were discovered in the "A" cluster, next to heavily burnt fragments of vessels. The settlement itself is dated back to the phase $\mathrm{B}_{2}$ of the Roman Period, with the possibility of its functioning even in the Younger Roman Period (Kokowski 1991, 73, 75, 82, fig. 35, 37: b). In Nieszawa Kolonia, six weights occurred in features 116, 121 and within the cultural layer, with four specimens discovered in the first of the features, defaulting next to each other. The feature 116 is dated back to the phase $\mathrm{B}_{2} / \mathrm{C}_{1}-\mathrm{C}_{1 \mathrm{a}}$, while feature 121 , without sufficient chronological determinants, can only be generally related to the Roman Period (Stasiak-Cyran 2016, 41-43, 81, pl. XCIX: 1-4; C: 4). From the settlement in Oronne originate the fragment of a weight with preserved hole, discovered in a layer outside the features. This fact, along with the presence of multicultural materials on the site, do not allow for defining the chronology of that artefact. With high probability it can be only generally related to the Przeworsk culture (Czarnecka 2012, 123, 134-235, fig. 14: 21). In Puławy-Włostowice the weights were related to the feature 5/1973, but their exact number is difficult to determine. Two specimens were reconstructed - in about $3 / 4$ and $1 / 2$ - and 8 further fragments of at least two weights were recorded ${ }^{3}$. That feature, due to the presence of Krausengefässe type vessel's fragments, as well as to the observed stratigraphic relation with the Przeworsk culture's grave No. 5 from phase $\mathrm{B}_{2}{ }^{4}$, dates back to the younger stage of phase $\mathrm{C}_{2}-\mathrm{D}_{1}$ or even phase $\mathrm{C}_{3}-\mathrm{D}_{1}$ (Niezabitowska-Wiśniewska 2018b, 604-606, 610-611, fig. 3, 5; pl. I: 1) (Fig. 2).

Thus, more than one circular weight was discovered within three of the four mentioned sites, wherein they occurred in four features. In the case of the settlement in Nieszawa Kolonia, these are two hearths (features: 116, 121). Cluster A from Dobre is difficult to unambiguously interpret. It was formed by a compact accumulation of mostly heavily burned fragments of vessels, while the weights were found on its northern and south-western side. Burned vessels are interpreted as a trace of the rapid destruction of the settlement by fire. The feature from Puławy-Włostowice was distinct on the basis of the analysis of

${ }^{2}$ Cf. Reder 2018.

${ }^{3}$ Some fragments of weights, mainly of orange colour, were probably split during exploration, perhaps due to mistake it for the daub, defaulting at the same level. Fragmentarily preserved weights are very difficult to reconstruct. We only know that they had a circular shape.

${ }^{4}$ Cf. Niezabitowska-Wiśniewska 2018a, 421. 


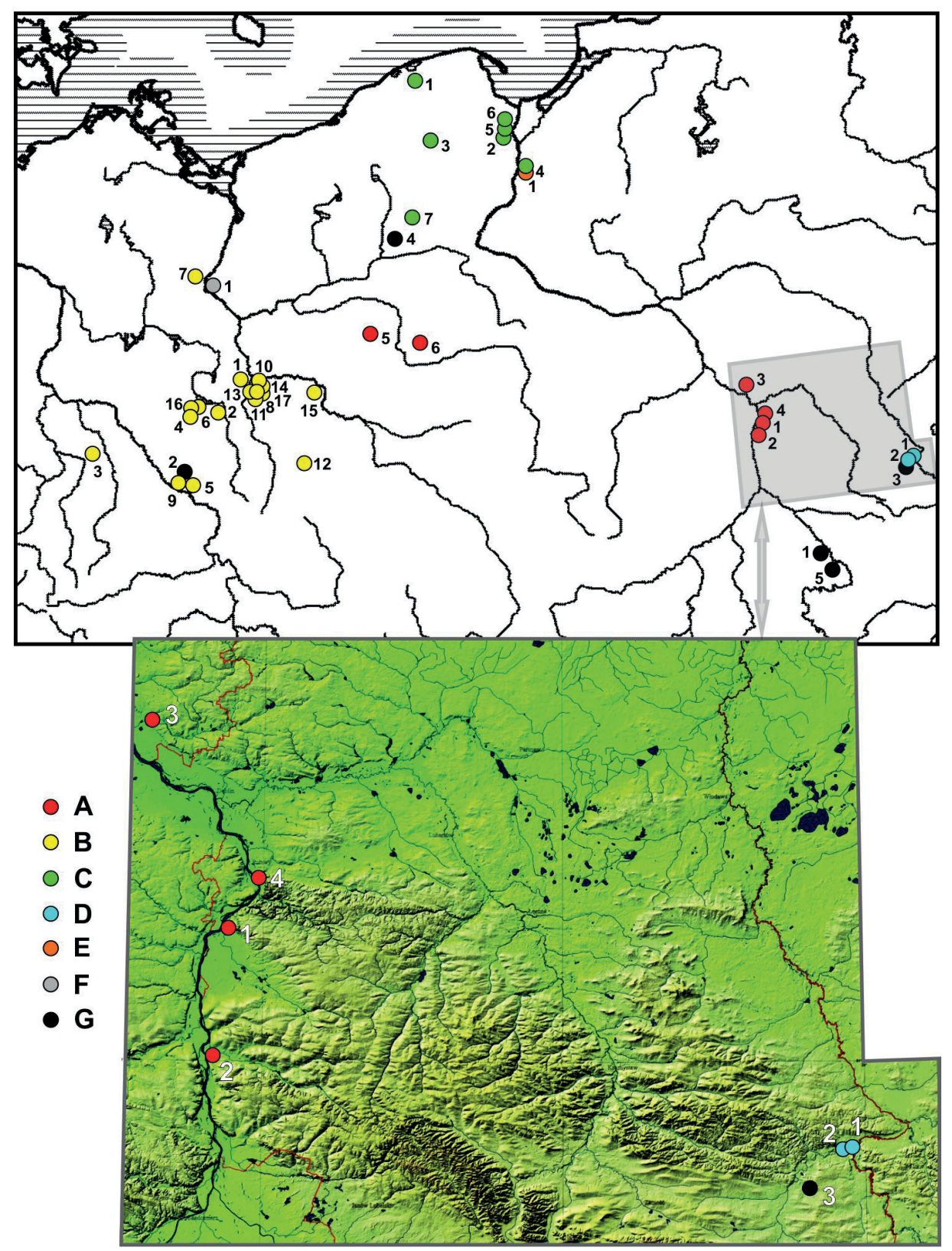

Fig. 1. Territorial spread of circular weights on sites dated back to the Roman Period and the early phase of the Migration Period included in the text. A - Przeworsk culture; B - Luboszyce culture / Elbe circle; C - Wielbark culture; D - Masłomęcz group; E - Oksywie culture; F Gustow group; G-doubtful finds or culturally unspecified. 
preserved artefacts from research in 1973 and archival drawing documentation in which it was described as a "cottage". Its limits were determined on the basis of the daub layer range. Many issues, which cannot be clarified at the moment, allow only cautiously to assume that it could have been a residential, shallow pit-house or an economic structure, although in that case the second hypothesis seems to be more probable.

From the further considerations, the dimensions of circular weights from the Przeworsk culture "Vistula" sites are a key issue. Unfortunately, most of them are preserved fragmentarily. Their diameters, although sometimes reconstructed, are similar and can be comprised in the range from 9.0/9.3 to $12 \mathrm{~cm}$, with predominating specimens of diameter oscillating about $11 \mathrm{~cm}$. The thicknesses of described weights are $3.2-5.3 \mathrm{~cm}$, while diameter of the holes closes within the range of 1.7/1.8-4 cm, most of which is about $2.5-4 \mathrm{~cm}$. Defining the original weight of the artefacts causes much more problems. The best preserved specimens from Puławy-Włostowice weigh respectively $259.5 \mathrm{~g}$ (specimen preserved in 1/2) and $290.8 \mathrm{~g}$ (specimen preserved in $3 / 4)^{5}$; on the other hand from Nieszawa Kolonia: from feature $116-147 \mathrm{~g}$ (best preserved), 68 and $61 \mathrm{~g}$ (preserved in approx. 1/2) and $34 \mathrm{~g}$ (fragment); from feature $121-261 \mathrm{~g}$. Preserved to this day clay weight from Dobre weighs about $287 \mathrm{~g}^{6}$. Thus, the weight of the analysed specimens oscillates between 147 and $290.8 \mathrm{~g}$, although it should be remembered that each of them has smaller or larger losses, which means that they originally weighed slightly more (Table 1).

The weights that I could studied myself are quite well fired. Specimens from Puławy-Włostowice bear traces of polishing, visible despite partial burnout of some of them. Visually, weights from Nieszawa Kolonia look very similar. Among the three dissected specimens discovered in Dobre, one weight was obtained; the

4 A: 1 - Dobre, 2 - Nieszawa Kolonia, 3 - Oronne, 4 - Puławy-Włostowice, 5 - Cieśle, 6 - Dzierznica; B: 1 - Breslack, 2 - Cottbus, 3 - Dewitz, 4 - Drehna, 5 - Dresdener Heide,

6 - Göritz, 7 - Herzsprung, 8 - Jazów, 9 - Kötitz (Coswig), 10 - Łomy, 11 - Luboszyce,

12 - Nowa Wieś, 13 - Polanowice, 14 - Pole, 15 - Stary Kisielin, 16 - Tornow-Lütjenberg,

17 - Stargard; C: 1 - Głuszyno, 2 - Klonówka, 3 - Leśno, 4 - Lipianki, 5 - Stanisławie, 6 - Ulkowy, 7 - Zakrzewska Osada; D: 1 - Gródek, 2 - Hrubieszów-Podgórze; E: 1 - Lipianki; F: 1 - Cedynia; G: 1 - Grodzisk Dolny (site 22), 2 - Niederebersbach, 3 - Terebiń, 4 - Wysoka Mała, 5 - Zamiechów

\footnotetext{
${ }^{5}$ Fragments of artefacts from Puławy-Włostowice have a weight of $64.84 \mathrm{~g} ; 67.75 \mathrm{~g} ; 57.49 \mathrm{~g} ; 41.55$ g; $20.27 \mathrm{~g} ; 16.33 \mathrm{~g} ; 10.71 \mathrm{~g}$ and $9.62 \mathrm{~g}$.

${ }^{6}$ I would like to thank very much to Marta Stasiak-Cyran from the Lublin Museum for weighing the circular weights from Nieszawa Kolonia and Dobre, kept in the museum's collections, and for taking photographs of these artefacts, with permission for publishing.
} 
Table 1. Przeworsk culture and Gustow group. Juxtaposition of the circular weights dimensions. $(\mathrm{R})$ - reconstruction of dimensions based on the drawing, $\sim=$ approx.

(approximately), - no data or no reconstruction possible

\begin{tabular}{|c|c|c|c|c|c|}
\hline site & quantity & $\begin{array}{l}\underset{(\mathrm{cm})}{\operatorname{diameter}} \\
\text { diamer }\end{array}$ & $\begin{array}{c}\text { thickness } \\
(\mathrm{cm})\end{array}$ & $\begin{array}{l}\text { hole } \\
\text { diameter } \\
\text { (cm) }\end{array}$ & $\begin{array}{c}\text { weight }(g) / \text { state of } \\
\text { preservation }\end{array}$ \\
\hline \multicolumn{6}{|c|}{ "Vistula" sites of the Przeworsk culture } \\
\hline $\begin{array}{l}\text { Dobre, } \\
\text { cluster A }\end{array}$ & \begin{tabular}{|l|}
3 \\
\\
\\
+13 \\
fragments \\
\end{tabular} & \begin{tabular}{|l|l|}
$\sim 11.5$ \\
- \\
-
\end{tabular} & \begin{tabular}{|l|}
$\sim 4.5$ \\
- \\
-
\end{tabular} & $\begin{array}{l}3.0 \\
- \\
-\end{array}$ & $\begin{array}{l}287 \text { (cavities) } \\
\text { - not preserved } \\
\text { - not preserved } \\
\text { - not preserved }\end{array}$ \\
\hline $\begin{array}{l}\text { Nieszawa Kolonia, } \\
\text { feature } 116\end{array}$ & 4 & $\begin{array}{l}9.3 \\
\sim 9.0 \\
\text { damaged } \\
- \\
\end{array}$ & $\begin{array}{l}\text { damaged } \\
\text { damaged } \\
\text { damaged } \\
-\end{array}$ & $\begin{array}{l}1.7-2.0(\mathrm{R}) \\
2.0-2.5(\mathrm{R}) \\
2.1-2.4(\mathrm{R}) \\
-\end{array}$ & $\begin{array}{l}147 \text { (cavities) } \\
68 \text { (approx. 1/2) } \\
61 \text { (approx. 1/2) } \\
34 \text { (fragment) }\end{array}$ \\
\hline $\begin{array}{l}\text { Nieszawa Kolonia, } \\
\text { feature } 121\end{array}$ & 1 & 9.5 & 5.0 & 3.0 & 261 (minor cavities) \\
\hline $\begin{array}{l}\text { Nieszawa Kolonia, } \\
\text { cultural layer, } \\
\text { trench 5, sector P }\end{array}$ & 1 & 12.0 & - & 4.0 & $\begin{array}{l}\text { specimen mostly } \\
\text { reconstructed using } \\
\text { plaster - weight } \\
\text { unreliable }\end{array}$ \\
\hline Oronne, stray find & 1 & $\sim 11.0$ & $\sim 3.2(\mathrm{R})$ & $\sim 1,8$ & fragment \\
\hline $\begin{array}{l}\text { Puławy-Włostowice, } \\
\text { feature 5/1973 }\end{array}$ & \begin{tabular}{|l|}
2 \\
\\
+8 \\
fragments
\end{tabular} & \begin{tabular}{|l|}
10.5 \\
$\sim 11.0-11.5$ \\
-
\end{tabular} & $\begin{array}{l}4.5 \\
\sim 5.3 \\
-\end{array}$ & $\begin{array}{l}2.1-2.6 \\
1.5-2.0 \\
-\end{array}$ & $\begin{array}{l}290.8 \text { (approx. } 3 / 4 \text { ) } \\
259.5 \text { (approx. } 1 / 2 \text { ) } \\
67.75 ; 64.84 ; 57.49 ; \\
41.55 ; 20.27 ; 16.33 ; \\
10.71 ; 9.62 ; 4.75 \\
\text { (fragments) }\end{array}$ \\
\hline \multicolumn{6}{|c|}{ sites from the western part of the Przeworsk culture } \\
\hline Cieśle, feature 428 & 1 & 8.0 & 5.0 & $\sim 2.0$ & - \\
\hline Cieśle, feature 429 & 2 & $\begin{array}{l}9.6 \times 9.4 \\
8.4 \times 8.1 \\
\end{array}$ & $\begin{array}{l}4.4 \\
4.84 \\
\end{array}$ & \begin{tabular}{|l|}
$3.2 \times 2.6$ \\
$2.27 \times 2.01$ \\
\end{tabular} & - \\
\hline $\begin{array}{l}\text { Dzierznica, feature } \\
2555\end{array}$ & 3 & \begin{tabular}{|l|}
13.8 \\
- \\
10.5 \\
\end{tabular} & $\begin{array}{l}3.6 \\
\sim 3.0 \\
\sim 4.0\end{array}$ & $\begin{array}{l}\sim 2.8 \\
- \\
-\end{array}$ & $\begin{array}{l}\text { preserved } \\
\text { fragmentarily }\end{array}$ \\
\hline \multicolumn{6}{|c|}{ semi-finished product of circular weight or "clay breadcake" } \\
\hline $\begin{array}{l}\text { (?) Zamiechów, } \\
\text { feature 464A }\end{array}$ & 1 & 6.8 & $3.2 / 3.4$ & 1.2 & partially drilled hole \\
\hline \multicolumn{6}{|c|}{ Gustow group } \\
\hline Cedynia, stray find & 1 & $\sim 11.0(\mathrm{R})$ & $\sim 6.0-6.5(\mathrm{R})$ & $\sim 2.3(\mathrm{R})$ & - \\
\hline Cedynia, layer III & 1 & $\sim 11.0(\mathrm{R})$ & $\sim 3.0-3.2(\mathrm{R})$ & $\sim 2.5(\mathrm{R})$ & - \\
\hline
\end{tabular}



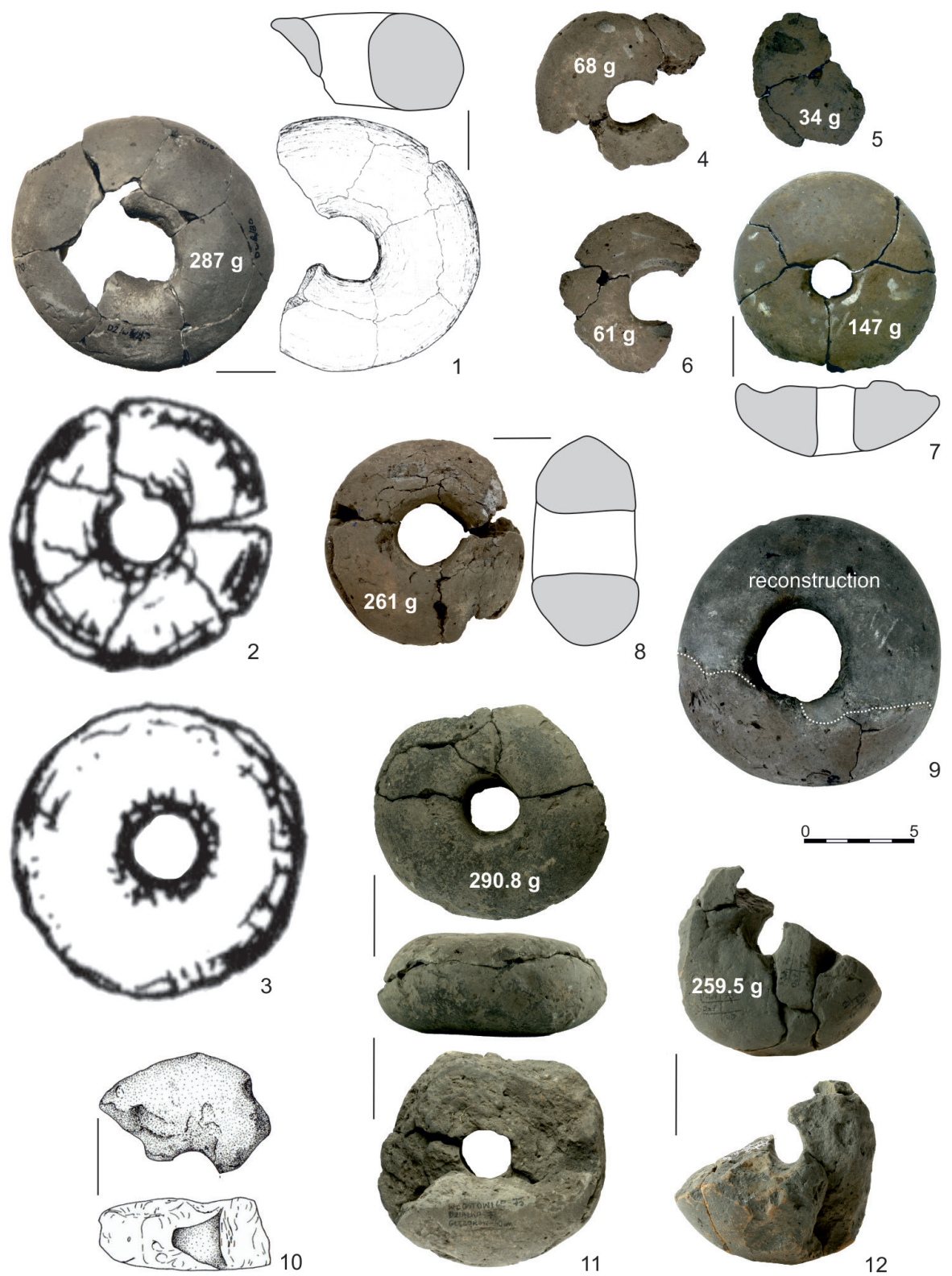

Fig. 2. Circular weights. "Vistula" sites of Przeworsk culture. 1-3 - Dobre, 4-9 - Nieszawa Kolonia (4-7 - feature 116, 8 - feature 121, 9 - trench 5), 10 - Oronne, 11-12 - PuławyWłostowice. Photo: M. Stasiak-Cyran (1, 4-9), T. Wiśniewski (11-12). After: Stasiak-Cyran 2016 (7, 8 - cross sections), Kokowski 1991 (1-3), Czarnecka 2012 (10), Niezabitowska-

Wiśniewska 2018b (11-12). 2-3 - approximate size 
others fell into pieces due to poor firing. There is, however, no information on the state of preservation of discovered 13 fragments, originating from an unspecified number of weights ${ }^{7}$. In the context of the aforementioned hypothesis about the destruction of the settlement by a violent fire, the fact that one weight has preserved to this day, as did numerous fragments of ceramics, and the other two - completely dissected - fell apart during collecting, is also somewhat puzzling. In theory, they should also burn out as a result of high temperature.

\section{DISTRIBUTION AND DATING OF CIRCULAR WEIGHTS ON POLISH LANDS AND IN NEIGHBOURING AREAS}

In order to answer the question contained in the title of the article, it is necessary to trace the spread and dating of the circular weights. The oldest ones are dated back to the Neolithic period (e.g. Burchard, Eker 1964, 275, pl. XXVIII: 2, 3; Łaszczewska 1966, 30, fig. 7; Chmielewski $2009^{8}$ - further literature there). With varying intensity, they are also recorded in sites from all subsequent periods and in various parts of Europe ${ }^{9}$. Similar weights are also recorded for the Early Middle Ages. Researchers recognizing them as loom weights assume that in Poland they remained in use until the $10 / 11^{\text {th }}$ century, which coincides with the end of the period of using warp-weighted looms (Antosik, Słomska 2018). Nevertheless, I know several of the circular weights that are dated much later $\left(12^{\text {th }}-\right.$ early $14^{\text {th }}$ century) (e.g. Grążawski 1988 , 330, fig. 12: 13-15; Rulewicz 1994 , fig. 20: 6-8; 45: 10; 58: 6; 59: 2). Single specimens are also related with the Modern Age (e.g. Chachlikowski et al. 2013, 211; Dębski, Krzepkowski 2013, 81, pl. 27: 7, 8; Grążawski 2013, 129, fig. 6). Interestingly, most of these "late" specimens are considered to be sinkers. I will return to all these issues.

Such a large chronological and territorial range of the circular weights occurrence probably is related to the "universal" shape and ease of their production (cf. Słomska 2015, 454; 2019, fig. 2: type 2). However, in this article, I will focus mainly on circular weights from the Roman Period and the early phase of the Migration Period, also making use of the analogies that differs chronologically and culturally.

${ }^{7}$ In the historical material from Dobre, partially kept in the collections of the Institute of Archeology of the Maria Curie-Skłodowska University, I could not find any fragment that could have undoubtedly originate from a circular weight.

${ }^{8}$ The circular weights were classified there as group B, including specimens of various shapes, but having one hole placed in their plane of symmetry, vertically to it (Chmielewski 2009, 175-186, 195-214, fig. 101).

${ }^{9}$ E.g. Dolinescu-Ferche 1974, 30, fig. 11: 4; Schmidt 1961, 32, 146, fig. 17: A/b-c, B/e, f, i, k; 19: a; 20a: l-n; 1970, 49, 65, pl. 43: 2/c, b; 62: 1/a, b, e, f; 1976, 100-101, pl. 82: 1; 83: 2/a-b; 84: 1/g; Plunkett 1999; Schneider 1967, 317, fig. 6: 13; Grążawski 1988, 330, fig. 13-15. 


\section{Luboszyce culture ${ }^{10} /$ Elbe circle}

In the Roman Period and in the early phase of the Migration Period, circular weights occur most frequently in the settlement sites of the Luboszyce culture / Elbe circle, therefore they are often considered as characteristic element of this cultural unit. Usually, they were discovered in collections dated back to the $\mathrm{C}_{2}-\mathrm{C}_{3}$ phases of the Roman Period (Domański 1979, 62; 2010, 143-144 ${ }^{11}$; Kokowski 2004, 265, fig. 3; Żychliński 2011, 163, 166). However, they also occur in features related with the early phase of the Migration Period. The largest amounts of circular weights originate from Göritz, Lkr. Oberspreewald-Lausitz - 51 specimens $^{12}$ (Berg-Hobohm 2004, 53-59, Fig. 20, 22: 1-9, Plate 2:33) and from Herzsprung, Lkr. Uckermark - 53 specimens (Schuster 2004, 175-178). Interestingly, in the first of the settlements they were discovered in as many as 25 features, while only in one case occurring in a larger number (feature $759-8$ specimens) ${ }^{13}$. While in Herzsprung 52 of 53 artefacts were recorded in one feature - No. $17^{14}$ (Table 2, 3). Other sites include: Breslack, Lkr. Oder-Spree, site 1 - 7 weights (Geisler 1976, 141-158; Domański 2010, 172, pl. 12: 1-4, 8); Cottbus, Kr. Cottbus - 4 weights (Leube 1975, 36, 112-113, pl. 22: 5-8; Domański 1979, 224225); Dewitz (Taucha), Lkr. Nordsachsen -1 weight (Meyer $1971^{15}$, 219, fig. 125: 15); Drehna, Lkr. Dahme-Spreewald - 3 weights (Leube 1975, 118; Żychliński 2011, 166); Dresdener Heide, Stadtkr. Dresden - 1 weight (Meyer 1971, 55-61, fig. 27: 8); Jazów, Krosno Odrzańskie District - a total of 17 weights (Domański

${ }^{10}$ I deliberately skip here the discussion about the legitimacy of G. Domański's separation of the Luboszyce culture (cf. e.g. Schuster 2011) and I will use this name to organize information, both in relation to sites from the area of western Poland (Lubuskie, Dolnoślaskie voivodships) and from Brandenburg and Saxony in Germany.

${ }^{11} \mathrm{G}$. Domański considers circular weights as the determinants of the $3^{\text {rd }}$ stage of the Luboszyce culture development, which takes place during the period of its greatest prosperity (2010, 143-144, 159). He dates the phase III from the 2 nd quarter of the III century to the beginning of the 3rd quarter of the $4^{\text {th }}$ century (Domański 1979, 99-100).

${ }^{12} \mathrm{~S}$. Berg-Hobohm in the descriptive part regarding the weights specifies their total number at 51 specimens, with detailed description of 41 best preserved.

${ }_{13}$ Single weights were found in the following features: 81, 98, 341, 466, 746, 960, 1040 (+ fragment); 1060; 1091, 1881, 2666, 3675, 3845, 3886, 4040, 4981, 6915; two weights occurred in the following features: 971,1822 (+ 2 fragments), 2141, 3663, 6555; 3 in each: 1574 (+ 3 fragments), 4531 (Berg-Hobohm 2004, 162-163, 167-168, 171-172, 174, 176, 180-184, 189, 193-195, 198, 200, 208-209, Plates $2,3,5,6,8,9,12,13,15,18-20,23,24,36,39,41,43,45,47,51,57,58)$.

${ }^{14} 29$ circular weights were arranged in two parallel rows; 17 more in the cluster near the NW wall of the feature; 4 in his fill. The other two were found near the wall of the feature $17 \mathrm{~b}$ and in the post hole also connected to this building. The separation of mentioned feature $17 \mathrm{~b}$ is related to the two phases of use of feature 17. A single circular weight was also found in feature 8 (Schuster 2004, 43, 155-177).

${ }^{15}$ Summary of information on weights described in E. Meyer's work from 1971, cf:: Meyer 1976, 166-167. 
1985, 49, pl. XIII: a; 2010) ${ }^{16}$; Kötitz (Coswig), Lkr. Meißen, pit $1-2$ weights; pit 2 - 14 weights, including 6 complete; pit $4-2$ weights (Meyer 1971, 328-331, fig. 179: 1, 2; 180: 1-4, 6-14; 181: 4-5; Domański 1979, 62); Łomy, Krosno Odrzańskie District, site 2, building $4-1$ weight (Domański 2010, 217, pl. 37: 8); Luboszyce, Krosno Odrzańskie District, site 4 - 6 weights (Domański 2004, 279, 266; Kokowski 2004, 265, fig. 3); Nowa Wieś, Bolesławiec District, site 4, feature 141 fragments of weights (Pazda et al. 2007, 239, 247, fig. 30: c); Polanowice, Krosno Odrzańskie District, site 5, building 1 (44) - 14-16 weights (Domański 2010, 222, pl. 30); Pole, Krosno Odrzańskie District, site $15-9$ fragments of weights (Domański 2010, 223, pl. 31: 6, 7); Stary Kisielin, Zielona Góra District, site 6 - 4 specimens (Żychliński 2011, 167); Tornow-Lütjenberg, Lkr. OberspreewaldLausitz - 7 weights (Warnke 1973, 139-140, fig. 72); Stargard, Krosno Odrzańskie District, site 10/12, pit 2 - fragments of 3-4 weights (Domański 2010, 228, pl. 31: 27-28, 30, 34) $)^{17}$ (Fig. 3).

Sometimes, circular weights occur in these sites features along with weights of other shapes, usually pyramidal. In some of them, the circular specimens are the dominant type (e.g. Herzsprung, feature $17-52$ circular, 19 pyramidal ${ }^{18}$; Göritz, feature $1574-3$ circular, 1 pyramidal; Breslack -7 circular, 1 pyramidal); in others circular weights have the same numbers as pyramidal ones (e.g. Göritz, features 1881, 2666, 3663). In feature 8 from Herzsprung, the ratio of circular weights to pyramidal ones is 1:15 (Table 2,3 ).

The diameters of circular weights from the area of Luboszyce culture / Elbe circle oscillate between 6.0/6.5 and $12.9 \mathrm{~cm}$, but by convention they can be divided into two groups - small specimens with diameters from 6.0 to $9.9 \mathrm{~cm}$ and slightly larger specimens with diameters from 10 to $12.9 \mathrm{~cm}$. However, the first of them definitely dominate. After comparing the available data, it can be said that most of the weights from this cultural zone have diameters in the range of 7-9 cm. Apart from the round shape, a large part of them is also characterized by a slightly "barrel-shaped" cross-section. The thicknesses of these weights range from 2.1 to $6.0 / 6.2 \mathrm{~cm}$, while the larger thickness does not means the larger diameter.

\footnotetext{
${ }^{16}$ Jazów, site $3 \mathrm{a}$, building $2-2$ specimens; site $3 \mathrm{~b}$, building $2-4$ specimens; building $6-3$ specimens; building $7-3$ specimens; building $8-1$ specimen; building $23-1$ specimen; pit $5-1$ specimen; cultural layer - 2 specimens (Domański 2010, 192, 195-197, 200-201, 211, Plates 18: 8, 19; 19: $3-6 ; 20: 7-9 ; 21: 14,16,24 ; 22: 20 ; 22: 27 ; 23: 4 ; 27: 7,21)$.

${ }_{17}$ Perhaps also Niederebersbach, Lkr. Meißen, feature 2 (Meyer 1971, 334, fig. 183: 9).

18 Thus, a total of 72 weights were discovered in feature $17(17+17 \mathrm{~b})$. The already described manner of their arrangement in the feature (see footnote 14) can be related with the presence of two warp-weighted looms. It is more likely, however, that the weights from cluster, stacked on top of each other, were a kind of reserve. Originally, they could also be placed in a sack or bag and hung on a pole, or placed on a shelf (Schuster 2004, 181-182). A similar arrangement of weights - although of different shapes - is known e.g. from Ożarów Mazowiecki, Warsaw District, where some of the 36 weights lay in two parallel rows in the north-western part of the cottage, and some - in the northeastern part of it - were grouped on top of each other, next to a large stone (Barska 2001; 2004; $c f$. Słomska 2015, 452, 454).
} 

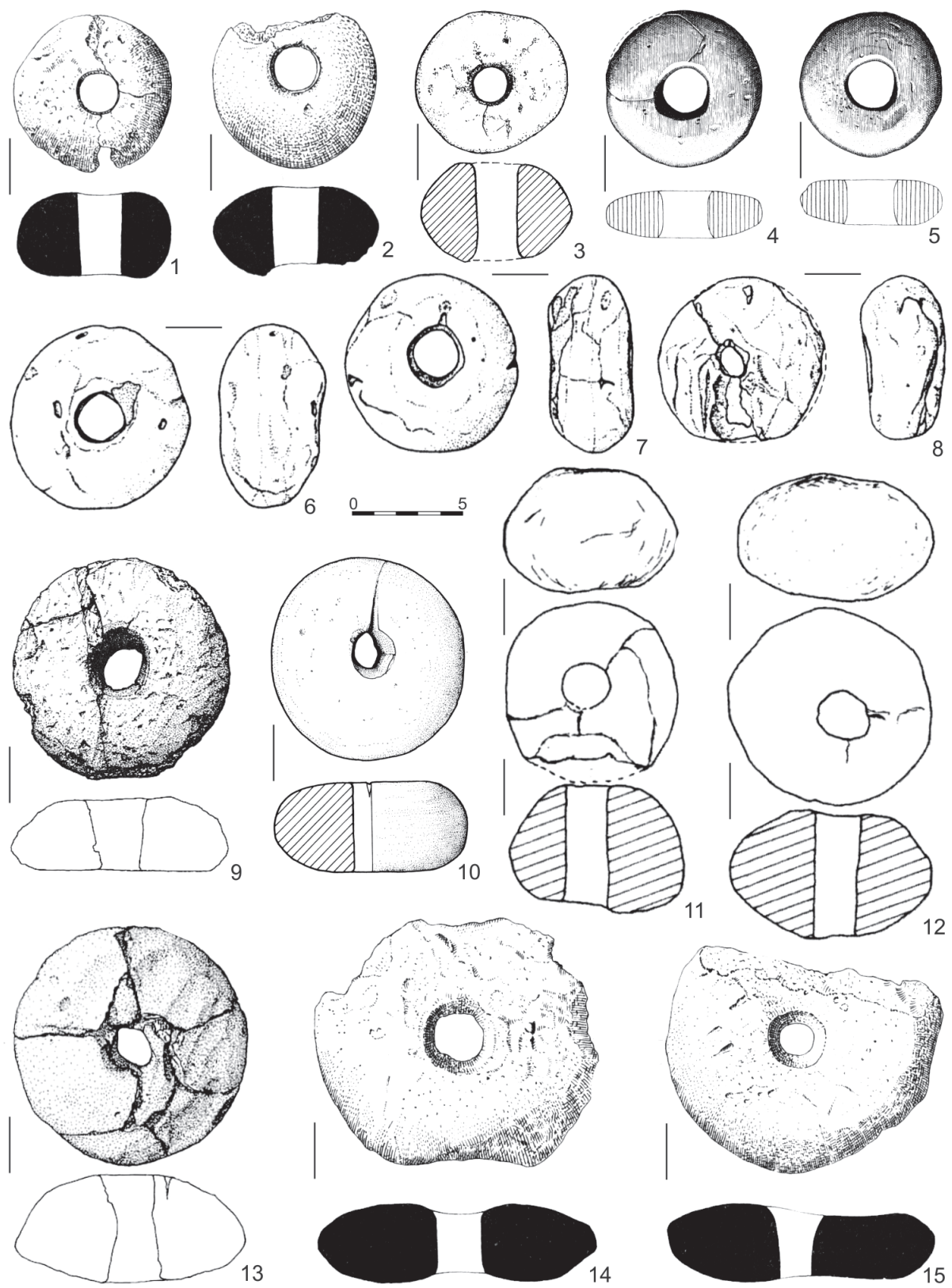

Fig. 3. Circular weights. Luboszyce culture / Elbe circle - the selection. 1-2, 14-15 - TornowLütjenberg, 3 - Jazów, 4-5 - Cottbus, 6-8 - Göritz, 9, 13 - Herzsprung, 10 - Breslack, 11-12 - Polanowice. After: Warnke 1973 (1-2, 14-15), Domański 1985 (3), Leube 1975 (4-5), Berg-Hobohm 2004 (6-8), Schuster 2004 (9, 13), Geisler 1976 (10), Domański 2010 (11-12) 
Table 2. Luboszyce culture / Elbe circle. Juxtaposition of the circular weights dimensions.

(R) - reconstruction of dimensions based on the drawing, $\sim=$ approx. (approximately), - no data or no reconstruction possible

\begin{tabular}{|c|c|c|c|c|c|}
\hline site & quantity & $\begin{array}{l}\text { diameter } \\
\text { (cm) }\end{array}$ & $\begin{array}{l}\text { thickness } \\
\text { (cm) }\end{array}$ & $\begin{array}{c}\text { hole } \\
\text { diameter } \\
(\mathrm{cm})\end{array}$ & $\begin{array}{l}\text { weight }(\mathrm{g}) / \text { state } \\
\text { of preservation }\end{array}$ \\
\hline Breslack & $\begin{array}{l}7 \\
+1 \\
\text { pyramid } \\
\text { weight }\end{array}$ & $\begin{array}{l}8.5-9.0 \\
\sim 8.6 \\
8.3-8.6 \\
\sim 7.5\end{array}$ & $\begin{array}{l}4.0 \\
4.1 \\
3.7 \\
2.5\end{array}$ & $\begin{array}{l}\sim 1.8-2.1 \\
2.2-2.5 \\
1.8-2.6 \\
1.6-2.0\end{array}$ & $\begin{array}{l}- \\
\text { only dimensions } \\
\text { of well-preserved } \\
\text { specimens are given; } \\
\text { all reconstructed }\end{array}$ \\
\hline Cottbus & 4 & 6.4-7.7 & $2.0-2.9$ & $\begin{array}{l}\sim 2.0-3.0 \\
(\mathrm{R})\end{array}$ & - \\
\hline Dewitz & 1 & 7.1 & 3.9 & $1.3-1.5$ & - \\
\hline Drehna & 3 & $\begin{array}{l}11.5 \\
8.8 \\
9.0\end{array}$ & $\begin{array}{l}2.1 \\
2.3 \\
2.3\end{array}$ & - & $\begin{array}{l}- \\
\text { one preserved in } \\
\text { approx. } 1 / 2\end{array}$ \\
\hline Dresdener Heide & 1 & 10.8 & 2.8 & 2.9 & $\begin{array}{l}- \\
\text { fragment }\end{array}$ \\
\hline $\begin{array}{l}\text { Jazów, } \\
\text { site } 3 \text { a building } 2\end{array}$ & 2 & - & - & - & in fragments \\
\hline $\begin{array}{l}\text { Jazów, } \\
\text { site } 3 \mathrm{~b} \text {, building } 2\end{array}$ & 4 & $\begin{array}{l}9.1-9.8(\mathrm{R}) \\
9.0(\mathrm{R}) \\
7.2-8.0(\mathrm{R}) \\
7.5-8.0(\mathrm{R})\end{array}$ & $\begin{array}{l}4.8-5.0(\mathrm{R}) \\
4.0(\mathrm{R}) \\
5.0(\mathrm{R}) \\
4.0(\mathrm{R})\end{array}$ & $\begin{array}{l}1.8-2.0(\mathrm{R}) \\
2.2-2.5(\mathrm{R}) \\
1.5-2.0(\mathrm{R}) \\
1.8(\mathrm{R})\end{array}$ & - \\
\hline $\begin{array}{l}\text { Jazów, } \\
\text { site } 3 \mathrm{~b} \text {, building } 6\end{array}$ & 3 & $\begin{array}{l}8.5-9.0(\mathrm{R}) \\
7.5-8.0(\mathrm{R}) \\
7.0-7.8(\mathrm{R})\end{array}$ & $\begin{array}{l}4.0(\mathrm{R}) \\
3.0(\mathrm{R}) \\
3.0(\mathrm{R})\end{array}$ & $\begin{array}{l}1.8-2.0(\mathrm{R}) \\
1.5-2.0(\mathrm{R}) \\
3.0-4.0(\mathrm{R})\end{array}$ & - \\
\hline $\begin{array}{l}\text { Jazów, } \\
\text { site } 3 \mathrm{~b} \text {, building } 7\end{array}$ & 3 & $\begin{array}{l}7.0-8.5(\mathrm{R}) \\
- \\
-\end{array}$ & $\begin{array}{l}3.8(\mathrm{R}) \\
- \\
-\end{array}$ & $\begin{array}{l}2.8-3.0(\mathrm{R}) \\
- \\
-\end{array}$ & $\begin{array}{l}- \\
\text { fragment } \\
\text { fragment }\end{array}$ \\
\hline $\begin{array}{l}\text { Jazów, } \\
\text { site 3b, building } 8\end{array}$ & 1 & $7.0(\mathrm{R})$ & $4.3(\mathrm{R})$ & $1.8-2.0(\mathrm{R})$ & - \\
\hline $\begin{array}{l}\text { Jazów, } \\
\text { site 3b, building } 23\end{array}$ & 1 & $7.0(\mathrm{R})$ & $3.8(\mathrm{R})$ & $2.0-2.5(\mathrm{R})$ & - \\
\hline $\begin{array}{l}\text { Jazów, } \\
\text { site } 3 b \text {, pit } 5\end{array}$ & 1 & $9.0-9.8(\mathrm{R})$ & $4.0(\mathrm{R})$ & $2.2(\mathrm{R})$ & - \\
\hline $\begin{array}{l}\text { Jazów, } \\
\text { site } 3 \mathrm{~b} \text {, cultural } \\
\text { layer }\end{array}$ & 2 & $\begin{array}{l}7.0-7.5(\mathrm{R}) \\
7.5-8.0(\mathrm{R})\end{array}$ & $\begin{array}{l}3.6(\mathrm{R}) \\
3.5(\mathrm{R})\end{array}$ & $\begin{array}{l}1.1-1.3(\mathrm{R}) \\
1.2-1.8(\mathrm{R})\end{array}$ & - \\
\hline
\end{tabular}

cont. 


\begin{tabular}{|c|c|c|c|c|c|}
\hline site & quantity & $\begin{array}{l}\text { diameter } \\
(\mathrm{cm})\end{array}$ & $\begin{array}{l}\text { thickness } \\
\text { (cm) }\end{array}$ & $\begin{array}{c}\text { hole } \\
\text { diameter } \\
(\mathrm{cm})\end{array}$ & $\begin{array}{l}\text { weight }(g) / \text { state } \\
\text { of preservation }\end{array}$ \\
\hline $\begin{array}{l}\text { Kötitz, } \\
\text { pit } 1\end{array}$ & 2 & $\begin{array}{l}8.0-8.5 \\
\sim 8.7\end{array}$ & $\begin{array}{l}4.5 \\
5.9\end{array}$ & $\begin{array}{l}2.1-2.8 \\
1.8\end{array}$ & $\begin{array}{l}285 \\
\text { fragment }\end{array}$ \\
\hline $\begin{array}{l}\text { Kötitz, } \\
\text { pit } 2\end{array}$ & 14 & $7.0-8.7$ & $3.7-6.2$ & $1.4-3.2$ & $\begin{array}{l}6 \text { complete copies: } \\
210,215,230,235, \\
375,400 ; \\
\text { others in fragments }\end{array}$ \\
\hline $\begin{array}{l}\text { Kötitz, } \\
\text { pit } 4\end{array}$ & 2 & $\begin{array}{l}7.9 \\
8.3\end{array}$ & $\begin{array}{l}3.7 \\
3.6\end{array}$ & $\begin{array}{l}2.0-2.4 \\
1.6-2.0\end{array}$ & $\begin{array}{l}207 \\
237 \\
\end{array}$ \\
\hline Luboszyce, site 4 & 6 & $\begin{array}{l}8.2 \\
8.4 \\
8.6 \\
8.9 \\
9.2\end{array}$ & $\begin{array}{l}5.6 \\
4.8 \\
5.2 \\
4.8 \\
5.5\end{array}$ & - & - \\
\hline Łomy, building 4 & 1 & $7.5-8.5(\mathrm{R})$ & $3.0(\mathrm{R})$ & $1.5-1.8(\mathrm{R})$ & \\
\hline $\begin{array}{l}\text { Nowa Wieś, } \\
\text { feature } 141\end{array}$ & 1 & - & $\sim 3.8(\mathrm{R})$ & $\sim 2.1(\mathrm{R})$ & $\begin{array}{l}- \\
\text { fragment }\end{array}$ \\
\hline $\begin{array}{l}\text { Polanowice, } \\
\text { feature } 1\end{array}$ & $14-16$ & $7.5-9.0(\mathrm{R})$ & $5.0-6.0(\mathrm{R})$ & $1.8-2.8(\mathrm{R})$ & - \\
\hline Pole & $\begin{array}{l}9 \\
\text { fragments }\end{array}$ & $\sim 8.0-8,5(\mathrm{R})$ & - & - & - \\
\hline Stary Kisielin & 4 & - & - & - & - \\
\hline Tornow-Lütjenberg & $\begin{array}{l}\text { at least } 7: \\
\text { - large and } \\
\text { flat } \\
\text { - small } \\
\text { and high }\end{array}$ & $\begin{array}{l}\sim 12.0-12.9 \\
(\mathrm{R}) \\
\sim 7.2-7.5(\mathrm{R})\end{array}$ & $\begin{array}{l}\sim 3.0-3.3 \\
(\mathrm{R}) \\
\sim 2.4-3.6 \\
(\mathrm{R})\end{array}$ & - & $\begin{array}{l}\text { weight given for } 3 \\
\text { specimens: } \\
165 \\
300 \\
\sim 500\end{array}$ \\
\hline Stargard, pit 2 & $3-4$ & $\begin{array}{l}7.0-8.5(\mathrm{R}) \\
-\end{array}$ & - & - & $\begin{array}{l}- \\
\text { - fragments of } 2 \text { or } 3 \\
\text { specimens }\end{array}$ \\
\hline
\end{tabular}


Table 3. Herzsprung. Juxtaposition of the circular weights dimensions

\begin{tabular}{|c|c|c|c|}
\hline \multicolumn{4}{|c|}{ FEATURE 8} \\
\hline diameter $(\mathrm{cm})$ & thickness (cm) & hole diameter $(\mathrm{cm})$ & weight (g) \\
\hline $6.6-6.7$ & 3.6 & 1.7 & 155 \\
\hline \multicolumn{4}{|c|}{$\begin{array}{l}\text { circular weight }-155 \mathrm{~g}+15 \text { pyramidal weights (weight given is only for one specimen }-535 \\
\text { g) }\end{array}$} \\
\hline \multicolumn{4}{|c|}{ FEATURE 17 - filling } \\
\hline diameter $(\mathrm{cm})$ & thickness (cm) & hole diameter $(\mathrm{cm})$ & weight (g) \\
\hline $10.9-11.3$ & 4.7 & $1.7-2.4$ & 620 \\
\hline fragment & 4.7 & - & - \\
\hline fragment & 5.3 & - & - \\
\hline fragment & - & - & - \\
\hline \multicolumn{4}{|c|}{ FEATURE 17 - loom } \\
\hline diameter $(\mathrm{cm})$ & thickness (cm) & hole diameter $(\mathrm{cm})$ & weight (g) \\
\hline $8.4-8.6$ & 4.1 & $1.9-2.0$ & 275 \\
\hline 8.7 & 3.6 & $1.8-2.0$ & 260 \\
\hline $8.9-9.0$ & 3.8 & $1.5-1.9$ & 290 \\
\hline 9.0 & 4.3 & $1.2-2.1$ & 340 \\
\hline $8.7-9.0$ & 3.8 & $1.7-2.0$ & 285 \\
\hline $8.5-9.1$ & 4.0 & $1.5-1.7$ & 300 \\
\hline $8.7-9.1$ & 4.0 & $1.9-2.0$ & 290 \\
\hline $8.5-9.2$ & 4.0 & $1.8-2.3$ & 295 \\
\hline $8.9-9.3$ & 4.5 & $2.1-2.3$ & 360 \\
\hline 9.4 & 3.5 & $1.9-2.1$ & 275 \\
\hline $8.2-9.5$ & 4.3 & $2.1-2.3$ & 336 \\
\hline $8.8-9.5$ & 3.5 & $1.6-2.1$ & 270 \\
\hline $9.2-9.5$ & 3.2 & $2.0-2.5$ & 240 \\
\hline $8.8-9.6$ & 3.3 & $1.9-2.2$ & in fragments \\
\hline 8.9-9.6 & 4.0 & $1.7-2.0$ & 320 \\
\hline $8.9-9.7$ & 4.1 & $1.4-2.0$ & 335 \\
\hline 9.5-9.7 & 3.6 & $2.0-2.1$ & 325 \\
\hline 9.7 & 3.1 & $1.8-2.5$ & 230 \\
\hline 9.4-9.8 & 5.3 & $1.5-2.5$ & 465 \\
\hline 9.6-9.9 & 3.3 & $1.5-2.5$ & 245 \\
\hline $9.7-10.0$ & 4.4 & $1.8-2.2$ & 485 \\
\hline
\end{tabular}

cont. 


\begin{tabular}{|c|c|c|c|}
\hline diameter $(\mathrm{cm})$ & thickness $(\mathrm{cm})$ & hole diameter $(\mathrm{cm})$ & weight (g) \\
\hline 10.1 & 3.0 & $2.2-2.7$ & 245 \\
\hline $9.3-10.1$ & 3.5 & $2.6-2.7$ & 260 \\
\hline $9.5-10.1$ & 3.3 & $1.7-2.5$ & 250 \\
\hline $9.7-10.2$ & 3.0 & $1.7-2.2$ & 235 \\
\hline $9.0-10.5$ & 3.9 & $1.8-2.6$ & 315 \\
\hline $9.1-10.5$ & 3.2 & $2.0-3.0$ & 245 \\
\hline $9.6-10.5$ & 3.0 & $2.7-3.3$ & 240 \\
\hline $10.4-10.9$ & 3.6 & $1.8-1.9$ & 390 \\
\hline \multicolumn{4}{|c|}{$\begin{array}{l}\text { Total weight of } 29 \text { circular weights }- \text { minimum } 8401 \mathrm{~g}+9 \text { pyramidal weights } \\
\text { (without specified weight) }+1 \text { rounded triangular weight }(350 \mathrm{~g})\end{array}$} \\
\hline \multicolumn{4}{|c|}{ FEATURE 17 - depot } \\
\hline diameter $(\mathrm{cm})$ & thickness (cm) & hole diameter $(\mathrm{cm})$ & weight (g) \\
\hline 7.5-9.1 & 4.5 & $1.7-2.5$ & 290 \\
\hline $8.0-9.5$ & 5.7 & $1.7-2.0$ & 335 \\
\hline $8.6-10.0$ & 4.5 & $1.0-1.3$ & 350 \\
\hline 9.0 & 3.4 & $1.4-1.8$ & fragment \\
\hline 9.5 & 5.0 & 2.2 & 380 \\
\hline $9.6-9.7$ & 4.3 & $1.9-2.4$ & 345 \\
\hline 9.7 & 4.4 & $1.5-2.0$ & fragment \\
\hline $10.0-10.5$ & 4.7 & $1.7-2.0$ & fragment \\
\hline $10.1-10.6$ & 5.9 & 2.0 & 530 \\
\hline $10.5-10.6$ & 4.7 & $1.8-2.0$ & 465 \\
\hline $10.7-11.0$ & 5.1 & $1.6-1.9$ & 485 \\
\hline $10.8-11.6$ & 5.1 & 1.6 & 495 \\
\hline approx. 12.0 & 5.1 & - & 530 \\
\hline fragment & 5.1 & 1.5 & - \\
\hline fragment & - & - & - \\
\hline fragment & - & - & - \\
\hline 8 fragments & - & - & - \\
\hline \multicolumn{4}{|c|}{$\begin{array}{l}\text { Total weight of } 17 \text { circular weights - minimum } 4205 \mathrm{~g}+9 \text { pyramidal weights } \\
\text { (without weight specified) }\end{array}$} \\
\hline \multicolumn{4}{|c|}{ FEATURE $17 b$ - on the secondary deposit } \\
\hline diameter $(\mathrm{cm})$ & thickness (cm) & hole diameter $(\mathrm{cm})$ & weight (g) \\
\hline 9.5 & 3.5 & - & \\
\hline fragment & 4.6 & 2.0 & \\
\hline
\end{tabular}


Table 4. Göritz. Juxtaposition of the circular weights dimensions. = approx. (approximately), - no data or no reconstruction possible

\begin{tabular}{|c|c|c|c|c|}
\hline Göritz & quantity & $\begin{array}{l}\text { diameter } \\
(\mathrm{cm})\end{array}$ & $\begin{array}{l}\text { thickness } \\
\quad(\mathrm{cm})\end{array}$ & $\begin{array}{c}\text { hole } \\
\text { diameter } \\
(\mathrm{cm})\end{array}$ \\
\hline feature 81 & 1 & 6.9 & 3.3 & 1.0 \\
\hline feature 98 & 1 & - & - & - \\
\hline feature 341 & 1 & $\sim 7.0$ & - & 2.0 \\
\hline feature 466 & 1 & $\sim 7.0$ & - & - \\
\hline feature 746 & 1 & - & - & $\sim 1.9$ \\
\hline \multirow[t]{8}{*}{ feature 759} & \multirow[t]{8}{*}{8} & 6.5-7.0 & $3.2-3.7$ & 1.3 \\
\hline & & 8.0 & - & 1.7 \\
\hline & & $\sim 8.0$ & $3.4-3.6$ & 1.9 \\
\hline & & 8.0 & 5.3 & 1.6 \\
\hline & & 7.0 & 5.5 & 1.9 \\
\hline & & 7.0 & 3.3 & - \\
\hline & & 8.0 & 4.0 & - \\
\hline & & 7.0 & $\sim 4.0$ & - \\
\hline feature 960 & 1 & 7.8 & $3.9-4.1$ & $1.2-1.9$ \\
\hline \multirow[t]{2}{*}{ feature 971} & \multirow[t]{2}{*}{2} & 7.0 & - & $1.6-1.8$ \\
\hline & & 7.9 & - & $1.8-1.9$ \\
\hline feature 1040 & $\begin{array}{l}1 \\
+ \text { fragment }+ \text { pyramidal weight } \\
\text { fragment }\end{array}$ & 8.1 & - & $2.0-2.3$ \\
\hline feature 1060 & 1 & 7.5 & - & $1.0-1.2$ \\
\hline feature 1091 & 1 & $\sim 7.0$ & - & 1.5 \\
\hline \multirow[t]{3}{*}{ feature 1574} & \multirow{3}{*}{$\begin{array}{l}3 \\
+3 \text { fragments } \\
+1 \text { pyramidal weight }\end{array}$} & 7.4-8.0 & - & $1.4-1.7$ \\
\hline & & 7.4 & - & 2.0 \\
\hline & & $\sim 8.7$ & - & $\sim 2.0$ \\
\hline \multirow[t]{2}{*}{ feature 1822} & \multirow{2}{*}{$\begin{array}{l}2 \\
+2 \text { fragments }\end{array}$} & 6.5 & - & 1.6 \\
\hline & & 7.4 & - & 1.9 \\
\hline feature 1881 & $\begin{array}{l}1 \\
+ \text { pyramidal weight fragment }\end{array}$ & $6.3-7.5$ & - & $\sim 1.8$ \\
\hline \multirow[t]{2}{*}{ feature 2141} & \multirow[t]{2}{*}{2} & 7.5 & - & $1.8-2.0$ \\
\hline & & 7.0 & - & 1.8 \\
\hline feature 2666 & $\begin{array}{l}1 \\
+1 \text { pyramidal weight }\end{array}$ & - & - & - \\
\hline
\end{tabular}

cont. 


\begin{tabular}{|c|c|c|c|c|}
\hline Göritz & quantity & $\underset{(\mathrm{cm})}{\operatorname{diameter}}$ & $\begin{array}{l}\text { thickness } \\
\quad(\mathrm{cm})\end{array}$ & $\begin{array}{c}\text { hole } \\
\text { diameter } \\
(\mathrm{cm})\end{array}$ \\
\hline \multirow[t]{2}{*}{ feature 3663} & \multirow{2}{*}{$\begin{array}{l}2 \\
+2 \text { pyramidal weights }\end{array}$} & $7.0-8.0$ & - & $1.5-2.0$ \\
\hline & & $6.0-7.8$ & - & $1.6-2.5$ \\
\hline feature 3675 & 1 & $\sim 7.4$ & - & 1.8 \\
\hline feature 3845 & 1 & - & - & $1.2-1.6$ \\
\hline feature 3886 & 1 & $\sim 7.0$ & - & $\sim 2.0$ \\
\hline feature 4040 & 1 & 9.0 & - & 3.4 \\
\hline \multirow[t]{3}{*}{ feature 4531} & \multirow[t]{3}{*}{3} & 8.2 & - & $1.8-2.4$ \\
\hline & & 7.2 & - & $1.8-2.4$ \\
\hline & & 9.4 & - & 2.2 \\
\hline feature 4981 & 1 & 7.0 & - & $2.0-2.2$ \\
\hline \multirow[t]{2}{*}{ feature 6555} & \multirow[t]{2}{*}{2} & 8.4 & - & $1.6-2.5$ \\
\hline & & 9.0 & - & $1.7-2.3$ \\
\hline feature 6915 & 1 & 9.0 & - & 1.8 \\
\hline
\end{tabular}

It can be even said that the specimens with the largest diameters are at the same time the thinnest and vice versa - the smallest specimens have the greatest thickness. Thus, these weights certainly can not be considered as flat-spherical. The diameters of the holes in the analysed artefacts are diverse and range from 1 to $3 \mathrm{~cm}$. The weight of the Luboszyce culture specimens ranges from 155 to 620 $\mathrm{g}^{19}$, but most often it is about 300 grams ( $f$. Domański 2010, 143-144) (Table 2-4).

\section{Przeworsk culture}

It is well known that in the Przeworsk culture circular weights should be considered as rare. It is dominated by weights in the shape of a cone or pyramid with a truncated apex (e.g. Michałowski 2011, 166; Reszczyńska 2014; Słomska 2015, 452-454). In addition to the already mentioned "Vistula" sites of the Przeworsk culture, the circular specimens are also known from the western part of this culture ${ }^{20}$. They were recorded in such sites as: Cieśle, Poznań District,

19 The description of some of the artefacts I known did not contain information about their weight. Therefore, the weight range is based only on available data and may slightly differ from the actual state.

${ }^{20}$ Circular weights were also discovered at site of the Gustow group (cf. Schuster 2018, 163-165) in Cedynia, Chojna District, site $9-2$ specimens - stray artefact and layer III (Wołagiewicz 1960, 109, 130, pl. X: 5, 7; Sobucki 2008, 526; Maik 2012, 59, fig. 89: c-d). 
feature 428 - 1 specimen; feature 429 - 2 specimens (Sobucki 2008, 523-524; Żychliński 2008, 356, fig. 24: 1-3; 2011, 163-165, 167-168, fig. 1); Dzierznica, Środa Ślaska District, site 35, feature 2555 - 3 specimens (Sobucki 2008, 520522, fig. 4; Żychliński 2011, 166-167)21 (Fig. 4).

In mentioned sites, circular weights occur along with materials dated back from phase $\mathrm{C}_{1}$ to the early phase of the Migration Period. According to D. Żychliński (2011, 167-168), these items were adopted by the population of the Przeworsk culture from the people of the Luboszyce culture, which should be an evidence of increased contacts between representatives of these two cultural units in the younger part of the late Roman Period, with the possibility of preserving the "Luboszyce" tradition also during the Migration Period. I will return to this hypothesis.

Unfortunately, only the dimensions of the weights are described for the specimens from the western part of the Przeworsk culture, ignoring their weight. Their diameters range from 8 to $13.8 \mathrm{~cm}$, while the diameters of the largest number of specimens are in the range of $8-10 \mathrm{~cm}$. The thicknesses of these weights range from 3 to $5 \mathrm{~cm}$; hole diameters from 2 to $3.2 \mathrm{~cm}$ (Table 1).

Much more mysterious is a single specimen of a circular weight from the Przeworsk culture settlement in Zamiechów, Jarosław District (site 1, feature 464A). The specimen discovered there has a partially drilled hole, which makes it unique and difficult to interpret (Reszczyńska 2014, 129, 132, pl. I: 3; PůlpánováReszczyńska et al. 2017, 118, fig. 3.35: 3). The diameter of this weight $-6.8 \mathrm{~cm}$ - is also puzzling, much smaller than the diameters of other specimens known from the Przeworsk culture area, and finding analogies in the smallest specimens from the Luboszyce culture area. The "initial" hole, which allows interpret the specimen from Zamiechów as a semi-finished product, can confirm its purpose as a weight, to which I will return later. Problematic due to the lack of a hole, small dimensions (diameter - approx. 6-6.5 cm; thickness - approx. $3 \mathrm{~cm}$ ) and a somewhat "egg-like" shape is also a clay item discovered in feature 1 (1984) in Białobrzegi, Łańcut District, site 8. J. Podgórska-Czopek in her work from 1991 (1991a) interprets it as a loom weight and points out that in the same feature also numerous fragments of other weights occurred, without providing any information about their shapes. The presence of the Krausengefässe vessel fragment within the feature allows the author to combine feature 1 with the Przeworsk culture (Podgórska-Czopek 1991a, 174, footnote 2, pl. I: 2). J. Podgórska-Czopek also

${ }^{21}$ Perhaps a fragment of the circular weight also originates from feature 68 on the Przeworsk culture settlement in Grodzisk Dolny, Leżajsk District, site 22. Unfortunately, due to its condition, it is very difficult to reconstruct its diameter, which seems to slightly exceed $6 \mathrm{~cm}$. The author of the study herself described this object as a fragment of a spherical spindle whorl (?), at the same time considering it to be unusual for the Przeworsk culture. It does not exclude the possibility of recognizing it as an artefact on the secondary bed, related to the settlement of the Tarnobrzeg Lusatian culture (Podgórska-Czopek 2009, 13, 85, table I: 4). 

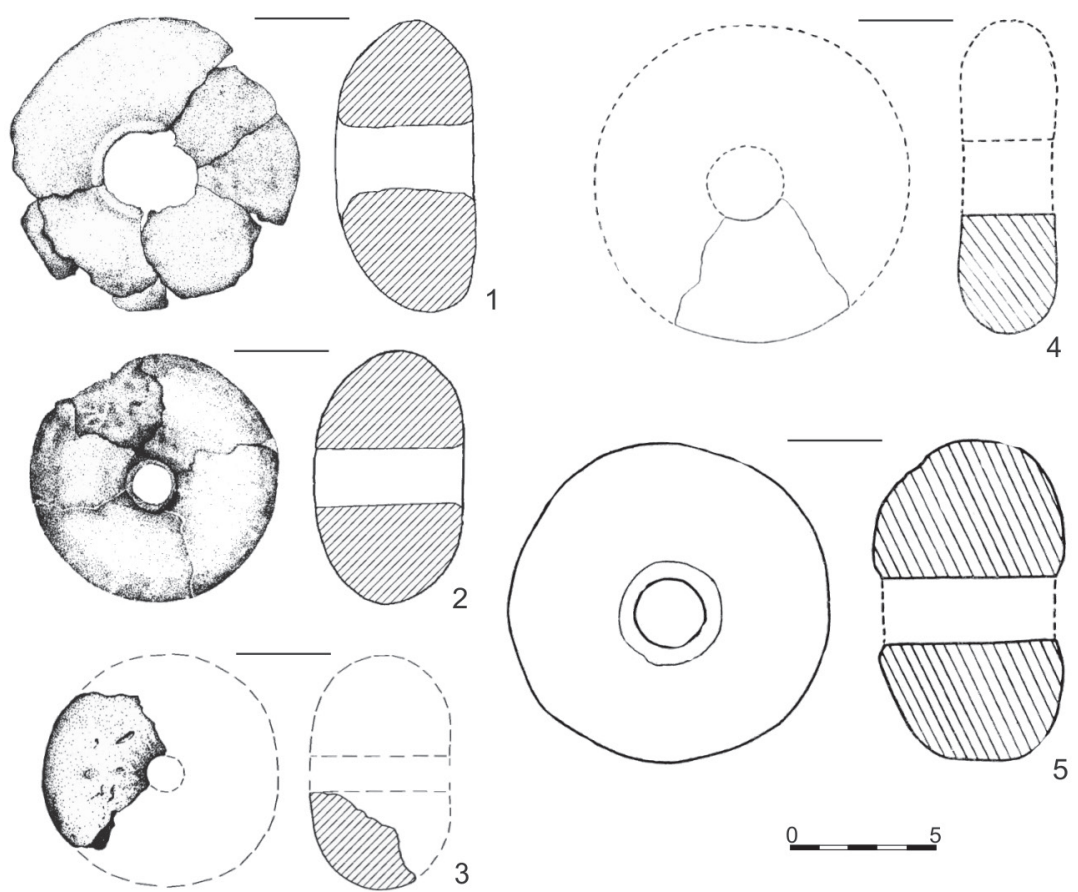

3
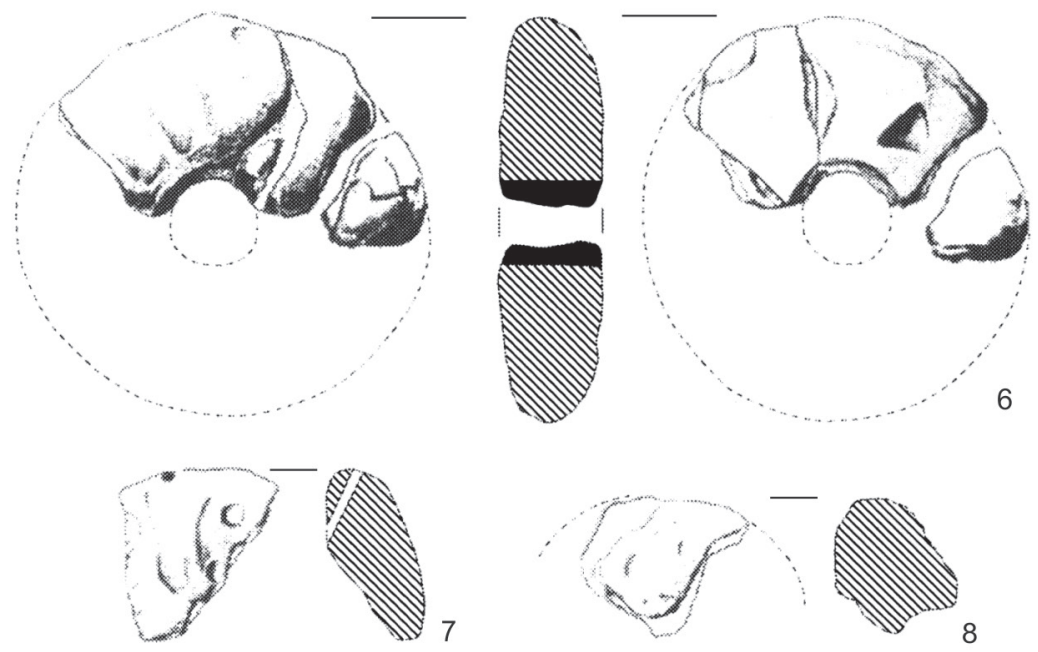

Fig. 4. Circular weights. Western part of the Przeworsk culture (1-3, 6-8) and Gustow group (4-5). 1-3 - Cieśle, 4-5 - Cedynia, 6-8 - Dzierznica.

After: Żychliński 2011 (1-3), Wołąiewicz 1960 (4-5), Sobucki 2008 (6-8) 
gives information that the closest analogies to the weight from Białobrzegi are known on the settlement in Grodzisk Dolny, Leżajsk District (site 3) 22 (PodgórskaCzopek 1991a, 174, footnote 2). In another work of the same author, also from 1991 (1991b), we can read that clay items originating from 1984 research on site in Białobrzegi are interpreted as so-called "clay breadcakes" [chlebki], without the possibility to indicate whether they should be related to the late Roman Period or the Early Middle Ages. The author repeat this interpretation in her work from 2006, while the feature 1/1984 from Białobrzegi dates back to the Early Middle Ages, writing that 2 "clay breadcakes" and 122 fragments of ceramics were discovered within (Podgórska-Czopek 2006, 89-90, fig. 3: 1-10). Thus, the artefact previously described as a weight, the author finally interprets as "clay breadcake". She also doesn't mention about the Krausengefässe ceramics. Similar inaccuracies
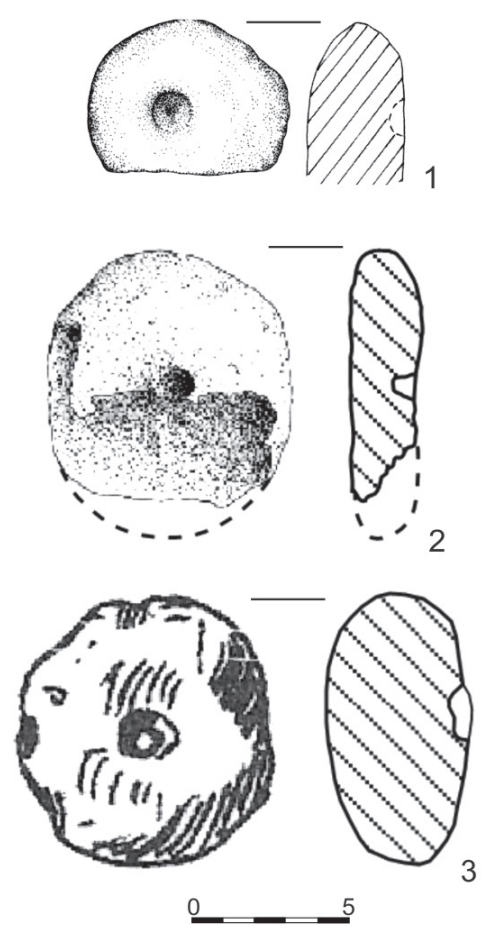
relate to the artefacts originating from site 3 in Grodzisk Dolny, mentioned as analogies to the "weight" from Białobrzegi. In fact, it was dated back to the Early Middle Ages, as well as a part of the settlement at site 22 in the same town (Podgórska-Czopek 1991b, 2006 ; 2009). The clay discs without holes discovered on both of these sites are certainly not weights, but so-called "clay breadcakes" (Podgórska-Czopek 1991b, 27-30; 2006, 105 Fig. 13; 2009, 201-208), widespread in the Early Medieval sites dated back to the $6^{\text {th }}-$ first half of the $7^{\text {th }}$ century ( $c f$. Stanciu $2012)^{23}$. Within the mentioned site 22

Fig. 5. Weight (?) from Zamiechów (1) and clay "breadcakes" displaying dents (2-3). After: Půlpánová-Reszczyńska et al. 2017 (1), Stanciu 2012 (2-3)

${ }^{22}$ This information probably caused that R. Reszczyńska placed artefacts from Białobrzegi and Grodzisk Dolny, site 3 among the disk weights - an analogy to the find from Zamiechów (Reszczyńska 2014, 132).

${ }^{23}$ In this work, "breads" from site 3 in Grodzisk Dolny were classified as clay "breadcakes" (type III) related to stone ovens stone-encircled hearth (6th C - first half of the 7th C) (Stanciu 2012, 270271), while "breads" from site 22 in this town to the group of clay "breadcakes" (type III) related to ovens carved in a native clay block or simple clay ovens (second half of the 5 th $\mathrm{C}-$ first half of the 7 th C) (Stanciu 2012, 270). 
in Grodzisk Dolny, clay breadcakes were also discovered in three features from the Roman Period, although it cannot be excluded that they were found on the secondary bed (Podgórka-Czopek 2009, 16, 31, 41, 208, pl. III: 7-8, 12-14, 16-17; X: 9; XIII: 9). The oldest finds of the clay breadcakes are related to the Chernyakhov culture (cf. Stanciu 2012, 254 fig. 1: A, 264-265, 269-270). Considering the above data, let's go back to the artefact from Zamiechów for a moment. Considering its shape and dimensions, it is possible to interpret it not as a semi-finished weight, but as a "clay breadcake" ${ }^{24}$. This hypothesis is indirectly confirmed by the fact, that some specimens of "breadcakes", although mainly from the $6^{\text {th }}$ - first half of the $7^{\text {th }}$ century, have various types of hollows, including located centrally on one side (Stanciu 2012, 263-264, fig. 9), which makes them similar to the artefact from Zamiechów (Fig. 5).

\section{Wielbark culture}

A small number of circular weights are known from the Wielbark culture area. According to J. Maik, discoidal specimens more frequently occur in Wielbark culture sites than specimens of other shapes, including the pyramidal ones (Maik 2012, 59-60, fig. 89). However, this hypothesis cannot be considered as certain, particularly in the light of insufficient recognition of the Wielbark culture settlements. Circular weights occurred at such sites as ${ }^{25}$ : Głuszyno, Słupsk District, feature $424^{26}$ (Machajewski 1995, 47, fig. 2.8: 4, 8; Maik 2012, 59, fig. 89: f-g); Klonówka, Starogard Gdański District, site 47, at the bottom of the cultural layer (Kalka 2005, 458-459, fig. 16: g; Maik 2012, 59, fig. 89: e); Leśno, Chojnice District, wreath $11^{27}$ (Walenta 2009, 33-34, pl. LXI: W-11/1; Maik 2012, 59, fig. 89: h); Lipianki, Kwidzyn District, feature $774-1$ specimen, feature 908 - 1 specimen, cultural layer - 3 specimens (Strobin 2015, 139, fig. 24: 4; 30: 6); Stanisławie, Tczew District, site 37 - 3 specimens (Gołębiewski 2003, 207, fig. 8: 16, 17; Paner et al. 2003, 23, fig. 26; Sobucki 2008, 524, fig. 6: 1; Maik 2012, 59, fig. 89: a-b); Ulkowy, Gdańsk District, site $1-2$ specimens (Ostasz 2003, 296, fig. 12; Sobucki 2008, 524, fig. 6: 2); Zakrzewska Osada, Sępólno Krajeńskie District, site 1 - 1 specimen, stray find (Szałkowska-Łoś, Łoś 2013, 44, pl. XLV: f) ${ }^{28}$ (Fig. 6).

${ }^{24}$ The diameter of most breadcakes is very similar of 7-9 cm, although specimens with both smaller $(5-6.9 \mathrm{~cm})$ and larger diameters (up to $11.8 \mathrm{~cm}$ ) are known (cf. Podgórska-Czopek 2009, 203 Table 14; Stanciu 2012, 257).

${ }^{25}$ P. Kalka mentions the Wielbark culture specimen of the circular weight from the settlement in Jastarnia, Puck District (Kalka 2005, 459), citing the work of K. Przewoźna. In fact, it is a $5.2 \mathrm{~cm}$ diameter spindle whorl described as "flat-cylindrical without recesses at the hole" (Przewoźna 1965, 205, 210, fig. 8:18).

${ }^{26}$ In the publication of H. Machajewski, these artefacts are described as spindle whorls.

${ }^{27}$ Discovered on the surface of a inhumation grave in the northern part, described as Modern or Medieval and lost.

${ }^{28}$ A. Sobucki provides information about an unpublished discovery of a single circular weight at 
Unfortunately, the place and context of discovery of most of these weights do not allow us to indicate the exact chronology of particular specimens. Generally, they can be dated from phase $\mathrm{B}_{2} / \mathrm{C}_{1}$ to phase $\mathrm{C}_{2}$ and $\mathrm{D}$.

In the context of the circular weights dating, I should mention about the feature 359 from Lipianki, dated back to the younger Pre-Roman Period and related to the Oksywie culture. In addition to the circular weight fragment (Fig. 6: 6), a trapezoidal-shaped specimen also was discovered within (Strobin 2015, 139, fig. 11: 5-6).

The dimensions of specimens from the Oksywie and Wielbark cultures can be included in the following ranges: diameters $-6.8-11.5 \mathrm{~cm}$; thicknesses $-1.8-5.0$ $\mathrm{cm}$; hole diameters $-1-3.0 / 3.2 \mathrm{~cm}^{29}$. As in the case of finds from the Przeworsk culture, their weight was not presented (Table 5).

\section{Masłomęcz group}

The alleged presence of the circular weights in the Masłomęcz group causes many interpretational problems. According to E. Banasiewicz (1989, 55-56, 59, fig. 8: 7) in Hrubieszów-Podgórze, Hrubieszów District, site 1A, in feature 60 - a shallow pit-house, 7 loom weights were discovered. Further the author writes that loom weights "occur in two varieties, the first was (feature 60) cylindrical, non-fired (fig. 8: 7) and the second in the shape of a pyramid with a quadrangular base" (Banasiewicz 1989, 59). In her earlier work, E. Banasiewicz informs only about fragments of loom weights from feature 11, 15 and a conical weight from feature 46 (Banasiewicz 1988, 51, 53, 58, pl. 5: 1). On the basis of provided data, with a high degree of caution, only the weight illustrated in the work from 1989 (Banasiewicz 1989, Fig. 8: 7; Niezabitowska-Wiśniewska 2018b, 611) can be considered as "deformed" (?) or burnt (?) circular weight, although the author describes it as cylindrical and unfired. By the courtesy of Anna Hyrchała from the Stanisław Staszic Museum in Hrubieszów, I also know that in the collection of this museum there is no weight that without a doubt can be considered as circular, nor any one that could correspond with the presumed specimen illustrated in the work of E. Banasiewicz (1989, fig. 8: 7). In addition to numerous fragments, two pyramid-shaped weights with a truncated apex from feature 46 and from feature 60 (!!!) have preserved. Therefore, at least one of the seven specimens from

\footnotetext{
the site in Wysoka Mała, Piła District, which dimensions are: diameter - approx. $9 \mathrm{~cm}$; thickness - about $5.5 \mathrm{~cm}$; hole diameter - $2.4 \mathrm{~cm}$ (Sobucki 2008, 526). He does not indicate, however, the cultural affiliation of this site, although the context and layout of the text suggests that it could be the Wielbark culture.

${ }^{29}$ Reconstruction of the diameters of specimens from the settlement in Ulkowy is impossible, due to the way they are illustrated and probably an erroneous linear scale (Ostasz 2003, fig. 12).
} 

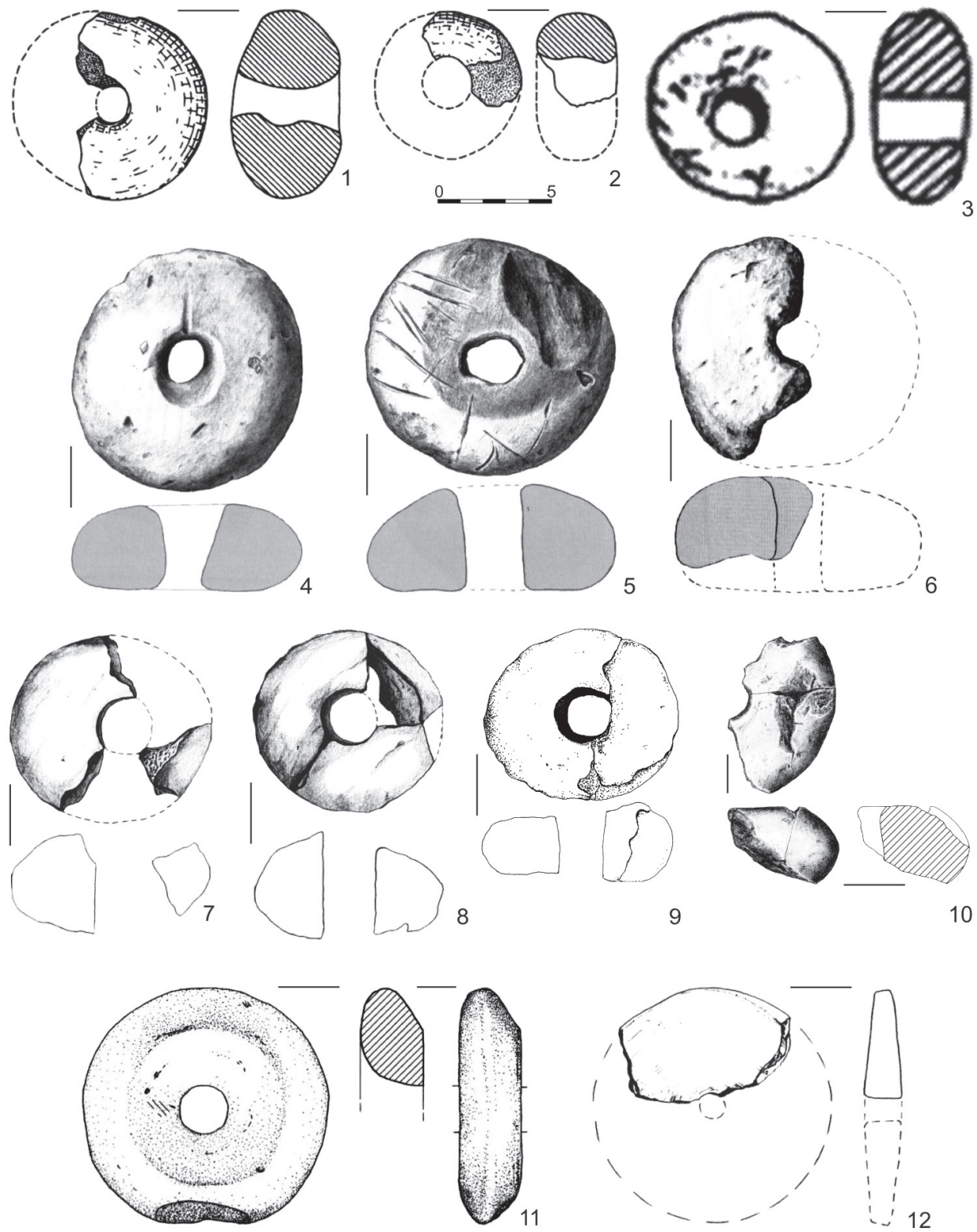

Fig. 6. Circular weights. Oksywie (6) and Wielbark cultures (1-5, 7-12). 1-2 - Głuszyno, 3 - Ulkowy, 4-6 - Lipianki, 7-9 - Stanisławie, 10 - Zakrzewska Osada, 11 - Leśno, 12 - Klonówka. After: Machajewski 1995 (1-2), Ostasz 2003 (3), Strobin 2015 (4-6), Gołębiewski 2003 (7-8), Paner et al. 2003 (9), Szałkowska-Łoś, Łoś 2013 (10), Walenta 2009 (11), Kalka 2005 (12). 3 - without scale 
Table 5. Wielbark and Oksywie cultures. Juxtaposition of the circular weights dimensions. (R) - reconstruction of dimensions based on the drawing, = approx. (approximately), - no data or no reconstruction possible

\begin{tabular}{|c|c|c|c|c|}
\hline site & quantity & diameter $(\mathrm{cm})$ & $\begin{array}{l}\text { thickness } \\
\text { (cm) }\end{array}$ & $\begin{array}{l}\text { hole } \\
\text { diameter } \\
(\mathrm{cm})\end{array}$ \\
\hline \multicolumn{5}{|c|}{ Oksywie culture } \\
\hline $\begin{array}{l}\text { Lipianki, } \\
\text { feature } 359\end{array}$ & $\begin{array}{l}1 \\
+1 \text { trapezoidal } \\
\text { weight }\end{array}$ & $\sim 11.0(\mathrm{R})$ & $5.0(\mathrm{R})$ & $2.0-2.1(\mathrm{R})$ \\
\hline \multicolumn{5}{|c|}{ Wielbark culture } \\
\hline $\begin{array}{l}\text { Głuszyno, } \\
\text { feature } 424\end{array}$ & 2 & $\begin{array}{l}\sim 8.5(\mathrm{R}) \\
\sim 6.8 \mathrm{~cm}(\mathrm{R})\end{array}$ & $\begin{array}{l}4.5-4.9(\mathrm{R}) \\
3.5(\mathrm{R})\end{array}$ & $\begin{array}{l}1.5(\mathrm{R}) \\
2.0(\mathrm{R})\end{array}$ \\
\hline $\begin{array}{l}\text { Klonówka, } \\
\text { cultural layer }\end{array}$ & 1 & $\begin{array}{l}7.0 \\
(\text { Kalka 2005) } \\
10.5(\mathrm{R})\end{array}$ & $\begin{array}{l}- \\
1.8(\mathrm{R})\end{array}$ & $\begin{array}{l}- \\
\sim 1.0(\mathrm{R})\end{array}$ \\
\hline $\begin{array}{l}\text { Leśno, } \\
\text { wreath } 11 \text { (maybe on the } \\
\text { secondary deposit) }\end{array}$ & 1 & $\sim 11.0-11.5(\mathrm{R})$ & $\sim 3.0(\mathrm{R})$ & $\sim 2.1(\mathrm{R})$ \\
\hline $\begin{array}{l}\text { Lipianki, } \\
\text { feature } 774\end{array}$ & 1 & $9.5-10.5$ & $3.8(\mathrm{R})$ & $1.7-3.2(\mathrm{R})$ \\
\hline $\begin{array}{l}\text { Lipianki, } \\
\text { feature } 908\end{array}$ & 1 & $11.0-11.5(\mathrm{R})$ & $4.7(\mathrm{R})$ & $2.7-3.0(\mathrm{R})$ \\
\hline $\begin{array}{l}\text { Lipianki, } \\
\text { cultural layer }\end{array}$ & 3 - fragments & - & - & - \\
\hline Stanisławie & 3 & $\begin{array}{l}\sim 8.5-9.0(\mathrm{R}) \\
8.5(\mathrm{R}) \\
7.5-8.5(\mathrm{R})\end{array}$ & $\begin{array}{l}\sim 4.0(\mathrm{R}) \\
2.5-4.0(\mathrm{R}) \\
2.5-3.5(\mathrm{R})\end{array}$ & $\begin{array}{l}\sim 2.1(\mathrm{R}) \\
2.1(\mathrm{R}) \\
1.9-2.2(\mathrm{R})\end{array}$ \\
\hline Ulkowy & 2 & \multicolumn{3}{|c|}{$\begin{array}{l}\text { no scale = no possibility to reconstruct } \\
\text { dimensions }\end{array}$} \\
\hline $\begin{array}{l}\text { Zakrzewska Osada, } \\
\text { stary find }\end{array}$ & 1 - fragment & \multicolumn{3}{|c|}{ dimensions retained $-7.0 \times 4.5$} \\
\hline Wysoka Mała (?) & 1 & $\sim 9.0$ & 5.5 & 2.4 \\
\hline
\end{tabular}


the last of the objects did not have a circular shape ${ }^{30}$. However, unpublished drawings of the three circular weights from Hrubieszów-Podgórze have been preserved in the archival documentation kept at the Museum in Hrubieszów. Unfortunately, no information on the exact location of discovery was found, although it cannot be excluded that they come from the mentioned feature 60 . These artefacts could not be found in the preserved historical material (Fig. 7: $5-8$, Table 6).

At present, the only preserved circular weights from the Masłomęcz group are unpublished ${ }^{31}$ specimens from feature 3/94 from Gródek, Hrubieszów District, site 6 (formerly 1D). Four such artefacts were discovered in this feature, one of them is almost complete, the other is preserved in about $1 / 2$; the other two preserved only in small fragments ${ }^{32}$. Apart from them, the feature also contained a cone-shaped weights, fragments of clay vessels, spindle whorls and bone tools (Fig. 7: 1-3, Table 6).

In the collection of the Stanisław Staszic Museum in Hrubieszów there are also 3 specimens of circular weights from Terebin, Hrubieszów District, site $71^{33}$ (inv. No. MH/A/8146). Unfortunately, these are surface finds, while the site itself is described as multicultural. Therefore, these facts do not allow for trusted relation of these specimens with the Masłomęcz group. Their dimensions and weight are similar to the specimens from the "Vistula" sites of Przeworsk culture $^{34}$ (Fig. 7: 9-11, Table 6).

${ }^{30}$ A lot of mutually exclusive information can be found in the work of J. Maik (2012, 59-60). Among the round (circular) weights, he mentions up to 7 specimens from Hrubieszów-Podgórze, probably referring to feature 60, applying to both works of E. Banasiewicz $(1988,1989)$, including a plate with a drawing of a weight but with a truncated cone shape. Anyway, he describes the same specimen among pyramid and cone-shaped weights. A bit surprisingly, a specimen from feature 60, previously included in circular ones, in the following part of the considerations is described as a failed product, and its shape as an intermediate between round and triangular, with his lustration in Figure 90, juxtaposition "pyramid, cone or prism weaving weights".

${ }^{31}$ The only publication devoted to research carried out in 1994 in site 6 in Gródek is a short report by J. Niedźwiedź and W. Panasiewicz (1995). The authors mention weights, but do not provide information about their shape or number. They also had not published their drawings. Drawings of two specimens of circular weights were provided in the research documentation (Niedźwiedź 1994).

${ }^{32}$ The dimensions of the best preserved specimens are: inv. No. MH/A/1913 - diameter - approx. $10 \mathrm{~cm}$, thickness - approx. $3.5 \mathrm{~cm}$; hole diameter - approx. $1.2-1.5 \mathrm{~cm}$, weight - $271.48 \mathrm{~g}$; inventory number MH/A/1912 - reconstructed diameter - approx. $10 \mathrm{~cm}$; thickness - approx. $5.6 \mathrm{~cm}$; hole diameter - approx. $2 \mathrm{~cm}$; weight - $254.87 \mathrm{~g}$; inventory number MH/A/1919 - fragment weight - 62.21 $\mathrm{g}$; inventory number $\mathrm{MH} / \mathrm{A} / 1927$ - fragment weight $-50.51 \mathrm{~g}$.

${ }^{33}$ In this place I would like to thank mgr Anna Hyrchała and mgr Anna Mucha both, for verifying information about weights from the Hrubieszów-Podgórze, as well as for the information and photographing of weights from Terebiń and Gródek, along with agreeing for its publication. I would also thank mgr Anna Hyrchała for the consultations regarding the reconstruction and the way of using of the vertical warp-weighted loom.

${ }_{34}$ The diameters of particular specimens are: 10-10.5; 8.5-8.8; approx. $9.2 \mathrm{~cm}$; weight $-220.67 \mathrm{~g}$; $405.75 \mathrm{~g}$ (specimens wholly preserved, with small defects) and $169.89 \mathrm{~g}$ (specimen preserved in about $1 / 2)$. 


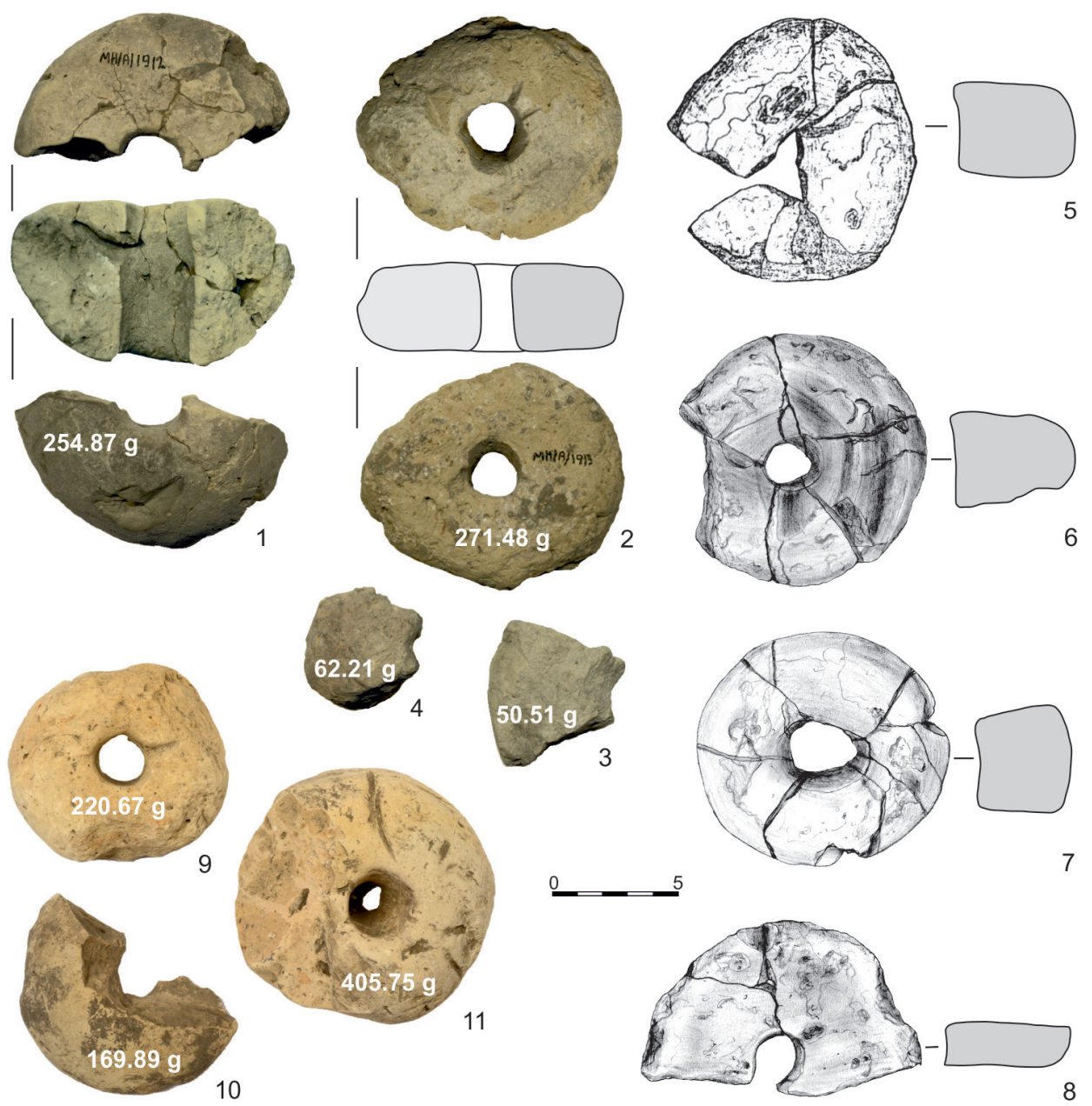

Fig. 7. Circular weights. Masłomęcz group (1-8) and surface finds from the Hrubieszów Basin (9-11). 1-4 - Gródek, site 6, 5-8 - Hrubieszów-Podgórze, 9-11 - Terebiń.

Photo: A. Hyrchała. After: Niedźwiedź 1994 (2 - cross sections), Banasiewicz 1989 (5), archival documentation by E. Banasiewicz kept at the Stanisław Staszic Museum in Hrubieszów (6-8)

Early Middle Ages and Middle Ages

As already mentioned, circular weights commonly occur in the Early Medieval and Medieval sites, also in Poland (e.g. Parczewski 1988, 91-92; Rulewicz 1994, 184-190; Jagodziński 2010, 184; 2015, 74; Auch et al. 2012, 100). Such finds can be helpful in recreating of the functions of these types of artefacts. I will back to 
Table 6. Masłomęcz group and surface finds from the Hrubieszów Basin. Juxtaposition of the circular weights dimensions. $(\mathrm{R})$ - reconstruction of dimensions based on the drawing, $\sim=$ approx. (approximately), - no data or no reconstruction possible

\begin{tabular}{|c|c|c|c|c|c|}
\hline site & quantity & $\begin{array}{l}\text { diameter } \\
(\mathrm{cm})\end{array}$ & $\begin{array}{l}\text { thickness } \\
\text { (cm) }\end{array}$ & $\begin{array}{l}\text { hole } \\
\text { diameter } \\
(\mathrm{cm})\end{array}$ & weight (g) \\
\hline \multicolumn{6}{|c|}{ Masłomęcz group } \\
\hline $\begin{array}{l}\text { Gródek, } \\
\text { site } 6, \\
\text { feature } 3 / 94\end{array}$ & $\begin{array}{l} \\
+ \text { at least } 2 \\
\text { pyramidal } \\
\text { weights }\end{array}$ & $\begin{array}{l}\sim 10.0 \\
\sim 10.0 \\
- \\
-\end{array}$ & $\begin{array}{l}\sim 3.5 \\
\sim 5.6 \\
- \\
-\end{array}$ & $\begin{array}{l}\sim 1.2-1.5 \\
\sim 2.0 \\
- \\
-\end{array}$ & $\begin{array}{l}271.48 \text { (cavities) } \\
254.87 \text { (approx. 1/2) } \\
62.21 \text { (fragment) } \\
50.51 \text { (fragment) }\end{array}$ \\
\hline $\begin{array}{l}\text { Hrubieszów- } \\
\text { Podgórze, } \\
\text { feature } 60\end{array}$ & $\begin{array}{l}\text { at least } 1(?) \\
+ \text { at least } 1 \\
\text { pyramidal weight }\end{array}$ & \begin{tabular}{|l|}
$\begin{array}{l}10.0-10.8 \\
\text { (deformed) }\end{array}$ \\
\end{tabular} & - & $\sim 3.7$ & - \\
\hline $\begin{array}{l}\text { Hrubieszów- } \\
\text { Podgórze, } \\
\text { feature } 60 \text { (?) }\end{array}$ & 3 & $\begin{array}{l}9.3-10.1(\mathrm{R}) \\
10.0(\mathrm{R}) \\
11.0(\mathrm{R})\end{array}$ & \begin{tabular}{|l|}
$4.4(\mathrm{R})$ \\
$3.8(\mathrm{R})$ \\
$\sim 1.8(?-\mathrm{R})$
\end{tabular} & $\begin{array}{l}\sim 2.0-3.5(\mathrm{R}) \\
\sim 2.0-2.3(\mathrm{R}) \\
\sim 2.0(\mathrm{R})\end{array}$ & $\begin{array}{l}- \\
\text { only drawings } \\
\text { preserved }\end{array}$ \\
\hline \multicolumn{6}{|c|}{ Hrubieszów Basin } \\
\hline $\begin{array}{l}\text { Terebiń, } \\
\text { site } 71, \\
\text { surface find }\end{array}$ & 3 & $\begin{array}{l}10.0-10.5 \\
8.5-8.8 \\
\sim 9.2\end{array}$ & $\begin{array}{l}\sim 2.0-2.5 \\
\sim 1.8-2.0 \\
\sim 2.0\end{array}$ & - & $\begin{array}{l}405.75 \\
220.67 \\
169.89 \text { (approx. 1/2) }\end{array}$ \\
\hline
\end{tabular}

this issue later. The sizes of such dated specimens that I know oscillate between $8.7 / 9.0$ and $13.5 \mathrm{~cm}$ in diameter, exceptionally $15-16 \mathrm{~cm}$; thicknesses from 2.5 to $4.5 \mathrm{~cm}$; hole diameter from 1.8 to $2.5 \mathrm{~cm}$, and weight from 219 to $373 \mathrm{~g}$. They also appear to be slightly flatter than the Roman Period weights. Sometimes they are clearly bi-conical in cross section, being reminiscent of the large spindle whorls (Fig. 8).

Regardless of the period for which the circular weights are dated, there is no agreement as to their function. There is a group of researchers that support only of the hypothesis connecting them with weaving (e.g. Chmielewski 2009, 203204; Żychliński 2011), a group interpreting them as a sinkers (e.g. Kotyza, Salač 1989; Rulewicz 1994, 184-189) and, as it seems, the largest group of researchers conservatively pointing to both possibilities (e.g. Sobucki 2008, 527; Maik 2012, 59 , footnotes 119, 121; Stasiak-Cyran 2016). Thus, the previous attribution of the circular weights functions should be considered as purely discretionary. Thus, I will try to analyse all the pros and cons of the two main hypotheses. However, I will start with the more obvious interpretation that combine the circular weights with weaving. 

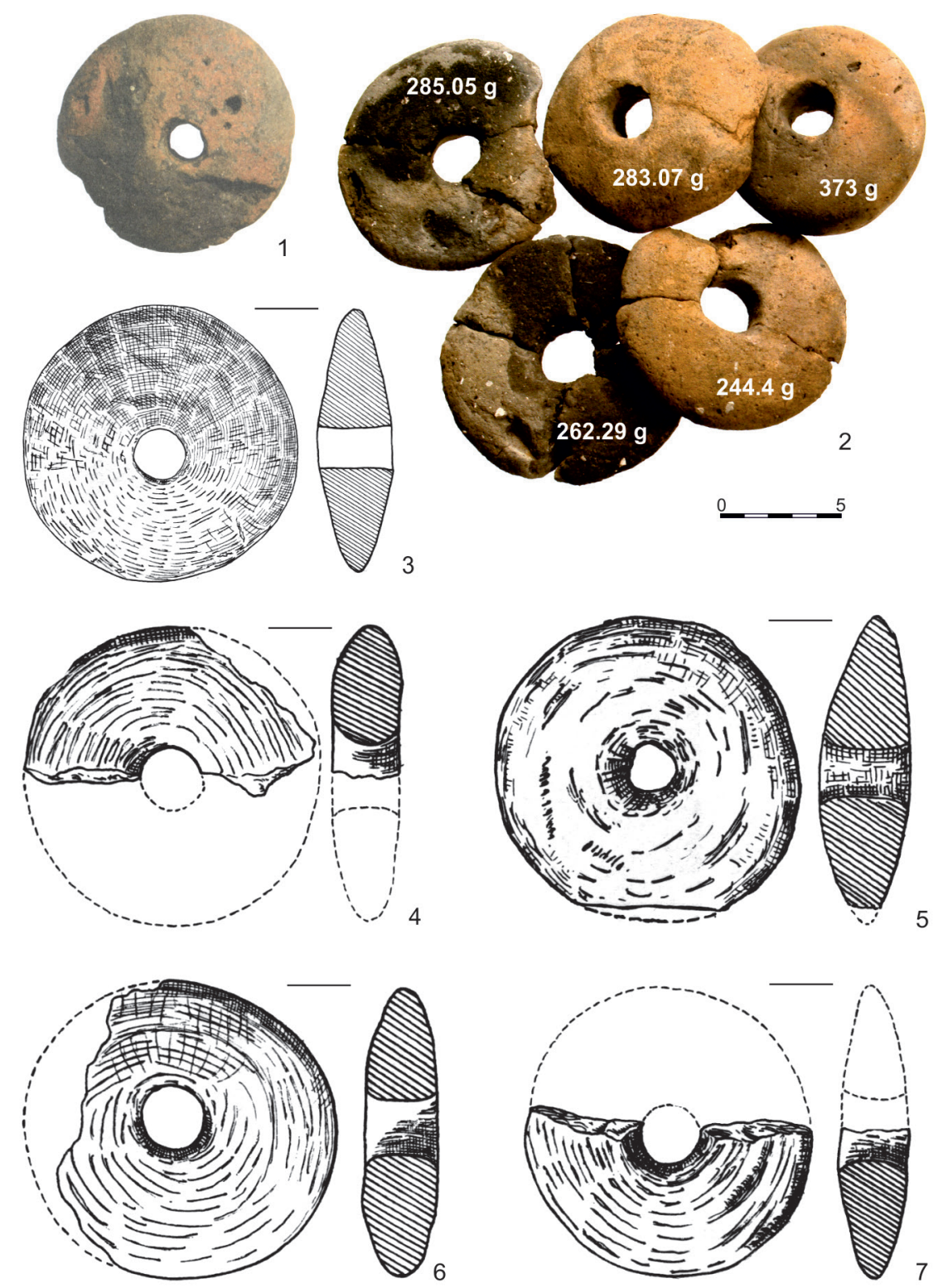

Fig. 8. Examples of the Medieval circular weights from the area of Poland. 1-2 - Janów Pomorski (Truso), 3, 5 - Szczecin, 4, 6-7 - Wolin.

After: Auch et al. 2012 (1), Jagodziński 2010 (2), Rulewicz 1994 (3-7) 


\section{CIRCULAR WEIGHTS AS THE LOOM WEIGHTS}

In most publications circular weights are almost automatically considered as elements of a vertical warp-weighted loom. Much has already been written about the weaving technology in prehistory, including the Central European Barbaricum, hence the citation of all publications and a detailed description of the weaving process I consider as unfounded from the point of view of this article. A prominent place in the literature is also occupied by the articles in the field of experimental archaeology, devoted to attempts of reconstruction of weaving workshops in various periods of Prehistory, including the use of circular weights (e.g. Hoffman 1994; Andersson 1999; Mårtensson et al. 2009; Andersson Strand 2011, 2012, 2018; Andersson Strand, Heller 2017; Andersson Strand, Mannering 2011; Ulanowska 2017, 2019 and many others).

The answer to the question: whether in the Roman Period and the early phase of Migration Period the circular weights could have been used as weights for warp threads in the weaving workshop seems to be unambiguous - they could. Nevertheless, it is important to provide the evidence justifying such statement. On that background, factors such as: discovery context, number and condition of the weights as well as their shape, weight and presence of use-wear traces, should be considered simultaneously with the use of analogies from other areas of Europe and the results of experimental research.

\section{Context of discovery, quantity and condition of weights}

Considering the place and context of the circular weights discovery, in terms of the possibility of relating them with a weaving workshop, the most useful are finds occurring in a large number within one feature. It is widely believed that the discovery of weights - regardless of their shape - defaulting in one or two parallel rows indicates the existence of a weaving workshop using the vertical warp-weighted loom. The length of the row or rows of weights determines the length of the workshop itself, and thus the width of the obtained fabric. This interpretation is substantiated by the relics of the looms, discovered next to the weights in the form of charred frames or post-holes. Ethnographic research conducted in Scandinavia reveals that modern weavers load the warp using 13 to 59 weights, but most often 20-30 of them (Hoffmann 1974, 24-29). Sometimes it is also assumed, that we can speak about the presence of a vertical weaving workshop in situ only when discovered weights occur in a group of at least 10 or 10/12 specimens (cf. Łaszczewska 1966, 40; Żychlińska 2016, 134). However, it should be remembered, that the number of weights in one loom depends on many factors, including the width and density of the woven fabric, the thickness of the 
thread or the weight of the weights, and cannot be perceived as a fixed value. I will back to this issue again.

In the case of the analysed circular weights from the Roman Period and the early phase of the Migration Period, as already mentioned, features containing more than 10 weights of this shape occur only in the Luboszyce culture / Elbe circle (e.g. Herzsprung ${ }^{35}$, feature 17; Kötitz, pit 2). They are also known from other areas of Europe, mainly northern and western, however they are dated back to the Early Middle Ages. For instance, features 9 and 10 from Dalem, Lkr. Cuxhaven, or feature 1 from Midlum-Northum, Lkr. Cuxhaven (Zimmermann 1982) should be mentioned here. An interesting find are also the remains of a weaving workshop from Pakenham, Suffolk, Great Britain, dated back to the $6^{\text {th }}$ century AD (Plunkett 1999). Much effort has also been devoted in the literature to the reconstruction of weaving on the basis of finds from Viking trading posts of Birka /Sweden/ and Hedeby /Germany/ (Andersson Strand 2011) (Fig. 9).

A valuable source of information about weaving, textiles and the tools used in this type of activity are prehistoric and ancient iconographic sources (e.g. Zimmermann 1988). The best known representations of weaving workshops are related to the Greek iconography ${ }^{36}$, where vertical looms are usually equipped with conical weights (Kaczmarek 2012, 193; 2013, 51-61). In the Roman iconography, the representations of vertical warp-weighted looms are much rarer or very schematic. An interesting exception and indirect proof for the possibility of using circular weights in weaving workshops is the tombstone from Nallihan (Asia Minor, today's Turkey). In the upper part of the burial stele a deceased couple under the arch was depicted; its lower part is divided into two zones - the right, related with the man and the left, reserved for the woman. On the last one, in addition to the various female attributes, a vertical loom with round weights is pictured (Feugère 2009 - more details there) (Fig. 10).

Thus, all the "copious" finds of ciruclar weights, results of experimental archaeology and iconographic sources clearly prove, that the disk weights could have been used in weaving workshops.

In contrast to the Luboszyce culture, within the Przeworsk communities, weights found in larger clusters are conical or pyramidal in shape, which allows them to be relatively certainly related with the remains of the vertical warp-weighted looms discovered in situ ${ }^{37}$. Some features containing larger amounts of these

${ }^{35} \mathrm{Cf}$. footnote 14 .

36 The most famous representation of the weaving workshop is known from a Greek vessel (lekythos) dated around 550-530 BC, kept at the Metropolitan Museum of Art in New York - https:// www.metmuseum.org/toah/works-of-art/31.11.10/ (all additional information there; compare also the cover of M. Hoffmann book of 1964).

${ }^{37}$ E.g. Głojkowo, Inowrocław District, site 9 (Bednarczyk 2000, 78, 80, 87 fig. 73-80); Inowrocław, District loco, site 95, features 723 and 733 (Bednarczyk 1987, 204, fig. 5: 733; 14: 1, ł); Kamień, Bełchatów District, site 2, feature 108 (Skowron 2010, 429-430, pl. XII-XIII); Ożarów Mazowiecki, 


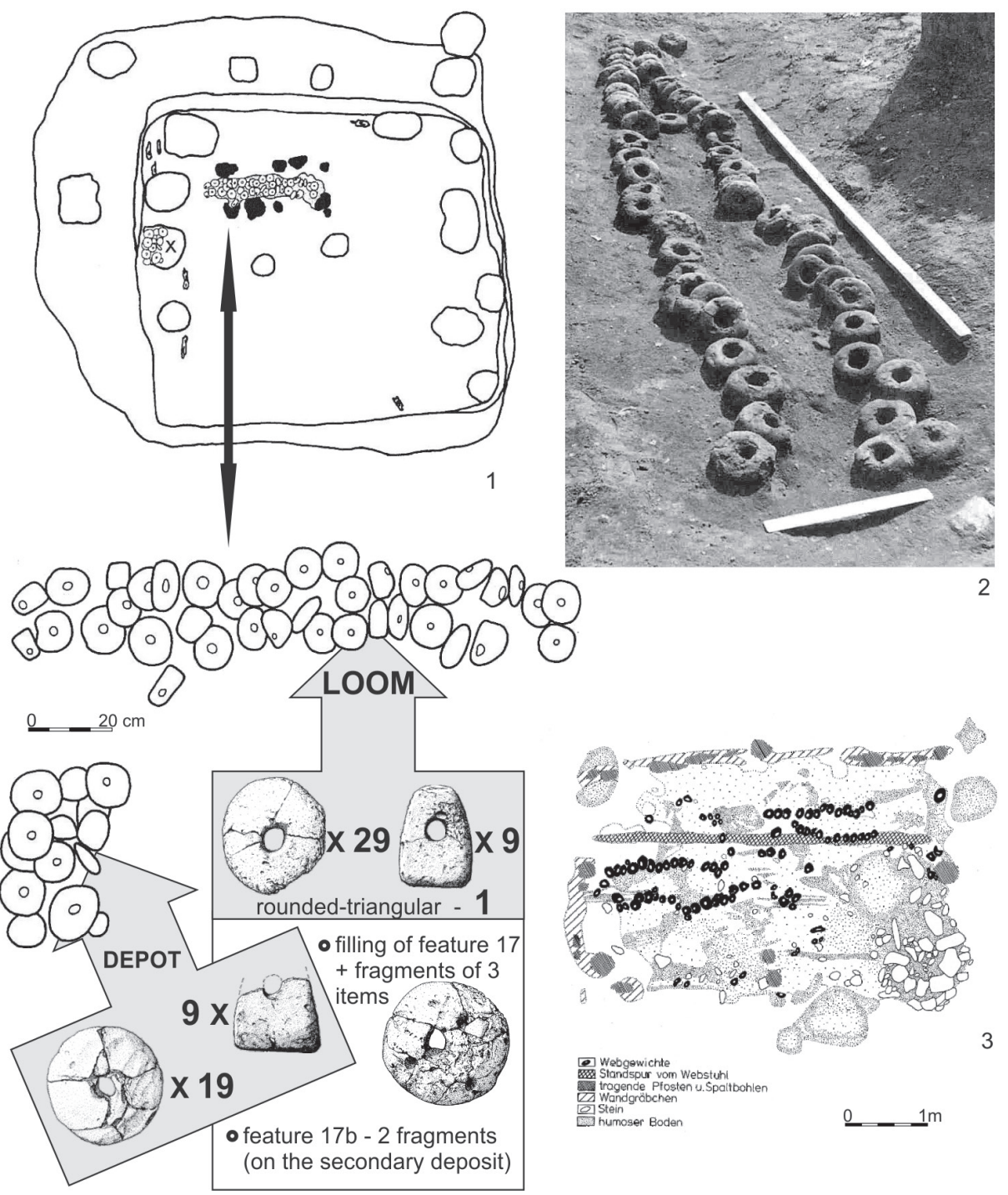

Fig. 9. Features with remains of weaving workshops using circular weights. 1 - Herzsprung, feature 17, 2 - Pakenham, Suffolk; 3 - Dalem, feature 9. After: Schuster 2004 (1), Plunkett 1999 (2), Zimmermann 1982 (3)

Warsaw District, site 23 (Barska 2001, 2004); Piwonice (now Kalisz-Piwonice), District loco, site 1, building 6 (Dabrowski 1958, 71-73, fig. 47, pl. XXXVI: 14); Poznań-Nowe Miasto, District loco, site 226, feature A.168 (Machajewski, Pietrzak 2008, 375-376, pl. 29); Toporów, Wieluń District, site 1, feature 17 (Kaszewska, Kaszewski 1963, PL. 56); Sobieszyn, Ryki District, site 14, feature 45 (Euczkiewicz 2008, 265, fig. 8). 


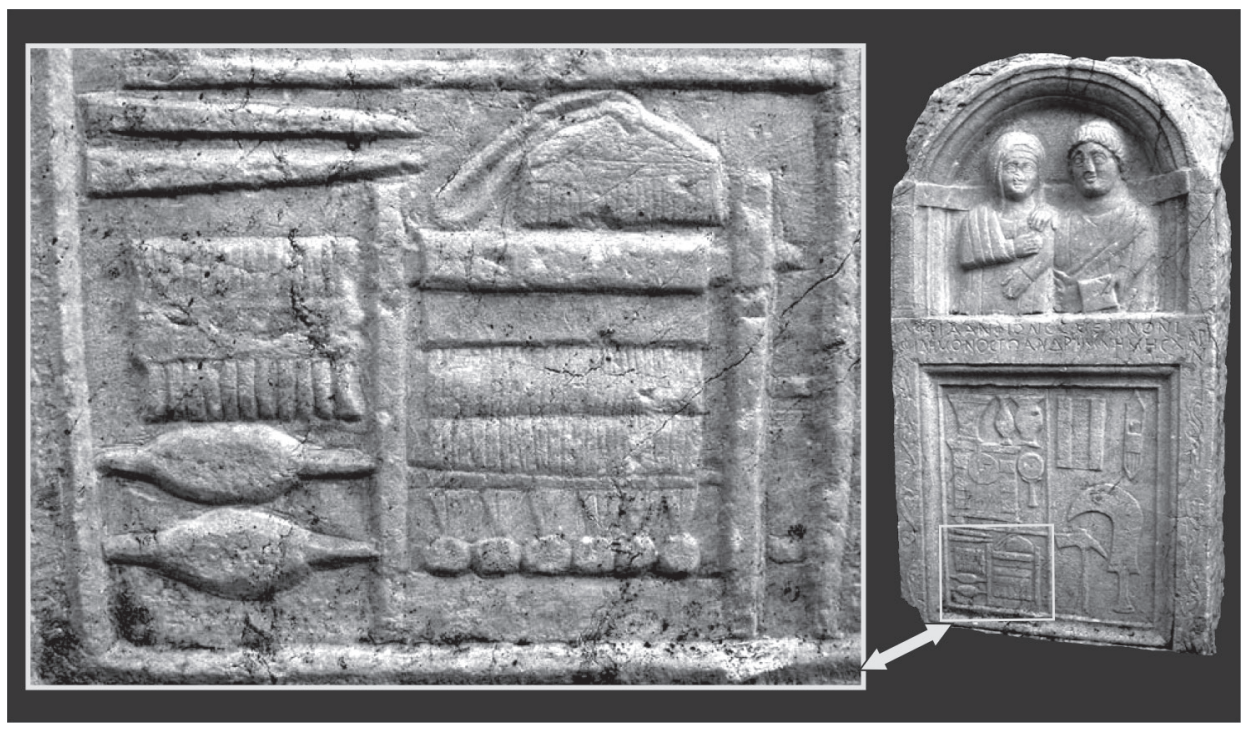

Fig. 10. Grave stele from Nallihan (Asia Minor) with the image of a vertical warp-weighted loom. After: Feugère 2009

artefacts are considered to be the remains of special buildings - weaving mills, similarly to feature 17 from Herzsprung (cf. Skowron 2016, 63-64). It is also believed, that some of the buildings, in which weaving or spinning took place, could have purposely lowered floor level, which guaranteed a relatively stable humidity inside. This, in turn, had a positive effect on the yarn used for weaving, especially linen one, reducing the risk of entangling and shattering (Zimmermann 1982, 133; cf. Michałowski, Sikorski 2011).

It is much more difficult, however, to interpret the weights, including circular weights, discovered singly or in small clusters (from 2 to 4 specimens), known from all mentioned sites of the Przeworsk and Wielbark cultures. This task is hampered by the fact, that they are often fragmented, which makes it difficult to restore their original number (e.g. Dobre, Puławy-Włostowice). Theoretically, the discovery of even single circular weight in the feature interpreted as residential, including houses on stilts (e.g. Cieśle ${ }^{38}$ ) allows to automatically recognized them as a relict of the "domestic" weaving workshop, which in such conditions could

${ }^{38}$ D. Żychliński, describing circular weights from two post-houses from Cieśle, emphasizes that no other traces were found, that could be interpreted as relics of weaving looms. It does not exclude the possibility, that the weights discovered there hung on the internal wall or on one of the structural posts of these buildings, and collapsed along with the wall (Żychliński 2011, 167). 
have been used after based on the house's wall ${ }^{39}$. However, it could not function with only one or two weights. Of course, the answer immediately comes to mind, that the other specimens have not preserved or were not recorded during the exploration of the daub layer, often occurring in such features. This is indirectly confirmed by the generally known fact, that weaving weights did not have to be well made to fulfil their function, which in turn affects their state of preservation ${ }^{40}$. However, a more prosaic explanation suggests almost spontaneously - perhaps weights discovered singly were thrown away or used secondary to construct "floor" or, less likely, to strengthen the walls of residential buildings, which can be evidenced by frequent finding them in clusters of daub ${ }^{41}$. The discarding or losing of weights, perhaps worn out or unnecessary, can also be proved by such discoveries in cultural layers or wells (e.g. Dzierznica), which - of course does not exclude the possibility of their original use as elements of the weaving workshops. It should also be remembered that weights, including circular ones, worn out quite quickly, especially when they were made carelessly, sometimes also by design intended for single use ${ }^{42}$ ( $c f$. Słomska 2015, 454).

An interesting place to find circular weights are features interpreted as hearths (e.g. Nieszawa Kolonia, features 116, 121), which clearly excludes the possibility of relating them to the remains of a weaving workshop found in situ. For proponents of interpreting of disc weights as a sinkers, this context of discovery is proof of drying the fishnet by the fire. Opponents of this theory believe, that it testifies the location of hearths near the weaving workshops for their better (additional) lighting during work (Chmielewski 2009, 203 - further literature there). Then, however, the hearths would have to been located inside the residential buildings or near special weaving mills, which cannot be said about the features from Nieszawa Kolonia. Therefore, also in these cases, it cannot be excluded that the weights were simply thrown away, and the discovery of them

39 The "skeleton" of the vertical warp-weighted loom consisted of two vertical poles joined together in the upper part by a horizontal beam. They could have been erected and leaned against the wall of the building, or the forming columns could have been dug into the ground (e.g. Słomska 2015, 452, fig. 1; Żychlińska 2016, 133). Some features containing remains of weaving workshops in situ are also interpreted, as already mentioned, as separate buildings - weaving mills (compare footnote 37 ).

${ }_{40}$ Neglectful weaving weights, often not fired but only dried, and thus their poor chance of preservation, is sometimes way of explanation of the numerous advantage of the spindle whorls over weights at the settlement sites (e.g. Słomska 2015; Żychlińska 2016, 134-135). Sometimes this disproportion is also related with the functioning of a larger number of spinning plants than weaving mills. This is explained by the fact that spinning was a relatively simple activity and did not require complicated equipment, while weaving already reveals the features of professional specialization (e.g. Skowron 2016, 63-64). This discussion also raises the question of the moment of appearance and common use of a vertical double-shaft loom that does not require the use of weights (e.g. Maik 2012, 82-83) or a horizontal loom where objects similar to weights were used only as weights suspended on brakes (e.g. Nahlik 1956; cf. Antosik, Słomska 2018).

${ }^{41} \mathrm{Cf}$. footnote 38 .

${ }^{42}$ This can be demonstrated by an attempt to interpret "spare" weights in features interpreted as weaving mills. cf. footnote 18 . 
in the hearths does not prejudge their function. Another explanation, although extremely difficult to prove, is an attempt to relate the weights found in hearths with the place of drying or firing (cf. Słomska 2015, 454).

Thus, the context of finding and the number of weights in the analysed features only partially allows to assign them a specific function. Large clusters of such artefacts may indicate the existence of a workshop in situ. However this is justified mainly in the case of the Luboszyce culture / Elbe circle. So far in Przeworsk culture, we only know large clusters of weights of other shapes, mainly conical ones ${ }^{43}$. The remaining, single finds of weights - regardless of their shapes - can be related with this field of production only by analogy to specimens discovered in clusters.

\section{Shape, weight and presence of use-wear traces}

The basic and extremely obvious criterion for consider the circular weights as weights in a vertical warp-weighted loom is presence of the hole. All certain finds of these artefacts meet this criterion. However, the large hole diameters of most circular weights are puzzling, as they seems proportionally much larger than the diameter of the holes in conical or pyramidal weights. In this context, it is worth considering how the circular weights were mounted on a vertical loom. Regardless of how many warp threads were loaded by one weight, they could not be attached directly. Most likely, a loops were first hung on each of the weights, to which the warp threads were attached (Chmielewski 2009, 205, fig. 108; Andersson Strand 2011) ${ }^{44}$ (Fig. 11). In addition to experimental research, this method of hanging weights can also be confirmed by traces or imprints of the cord visible on some specimens. The hypothesis of D. Żychlinski, that cord marks visible at the edges of the hole of one of the weights from Cieśle should be related with the stage of drying before firing, is rather unlike (Żychliński 2011). It is rather a use-wear trace. Similar are also visible, among others, on weights from Terebin or Lipianki. However, the reconstructed method of hanging the circular weights does not explain the size of their holes, although of course their large diameters could make these weights much more convenient to use. The cord forming the loop could also be successfully threaded through a much smaller hole. The explanation, however, can be very prosaic and related to the presumable process of circular weights production, which could be successfully carried out by joining together the two ends of a "roller" made of clay. The size of the hole in the such created ring depended on the length and thickness of the "roller" used to

${ }^{43} \mathrm{Cf}$. footnote 37 .

${ }^{44} \mathrm{~A}$ similar method of hanging also applies to weights of other shapes, which is confirmed by, among others, some iconographic representations $-c f$. footnote 36 . 


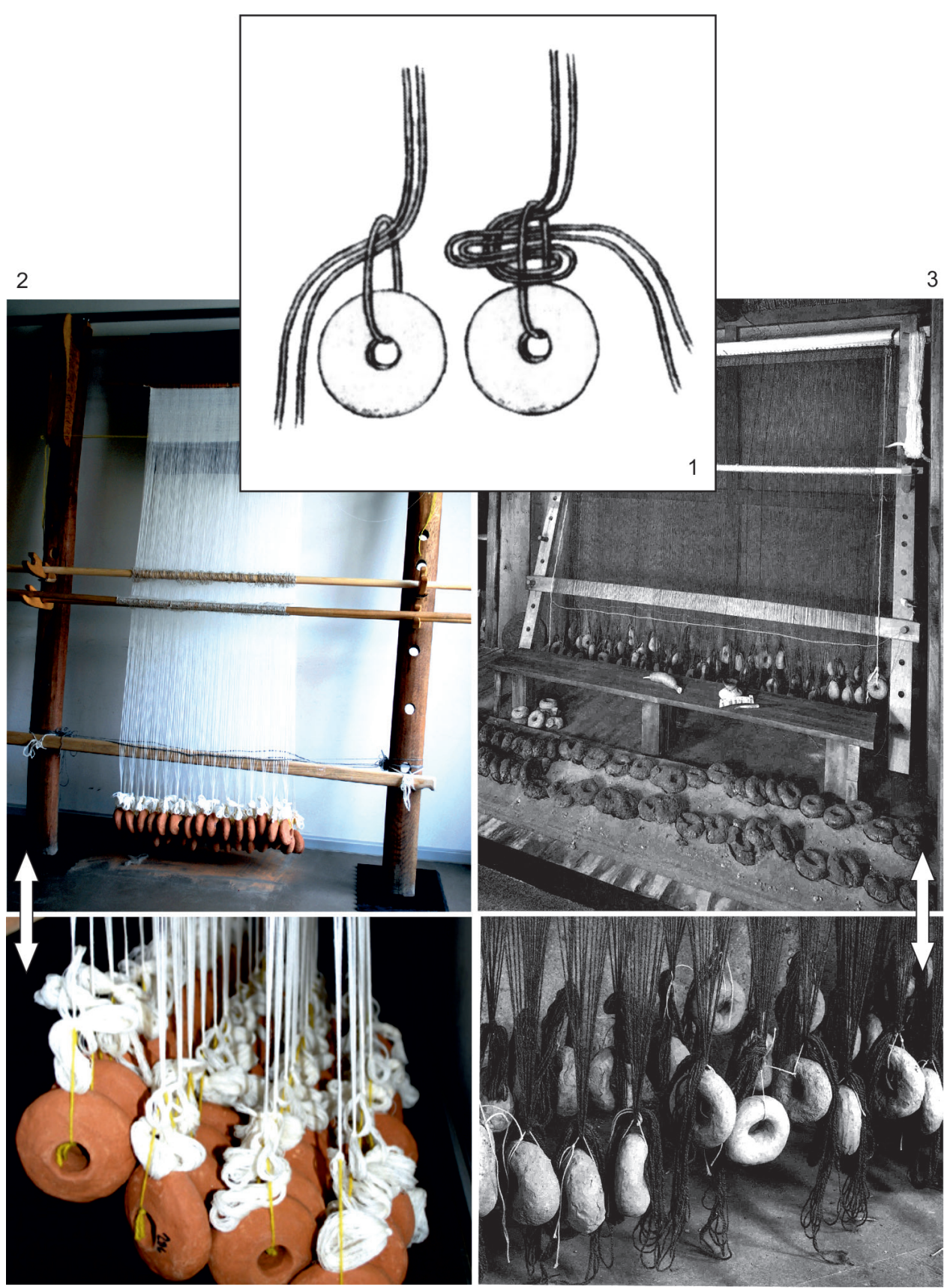

Fig. 11. Reconstruction of ways to hang the circular weights in a vertical warp-weighted looms. After: Chmielewski 2009 (1), Andersson Strand 2011 (2), Plunkett 1999 (3) 
produce the weight ${ }^{45}$. The relatively smaller diameters of the holes in the weights of other shapes can be explained by the necessity of "piercing" them in a piece of clay, shaped as a cone or a pyramid.

The weight of particular circular weights varies. It should be remembered, however, that it is strictly dependent on the size, including thickness, and thus the quantity and quality of the clay used in production. Its contemporary values may also be affected by the secondary burn-out of some specimens. Interestingly, the weight of circular weights most likely used in one weaving workshop can differ quite significantly (e.g. the weight of preserved weights from pit 2 in Kötitz is: $210,215,230,235,375,400 \mathrm{~g})$. Similar differences also apply to weights of other shapes. Indirectly, this may indicate that they were handmade and somehow "by eye", hence it is difficult to find two identical specimens ( $c f$. Słomska 2015, 454).

Mentioned values of weight are certainly sufficient to load the warp threads. The proportionally lower weight of circular specimens, in comparison to the "classic" weights ${ }^{46}$, in no way negates the possibility of their functional relation to the weaving workshop. More important is the question of how it affects the way they were used.

Experimental research reveals that the value of weight determines how many threads of a particular type can be attached to single specimen. Different types of yarn used on looms as warp threads require different stresses. It also seems that the thread diameter is not so much important as its weight, although usually thicker, heavy yarn requires more tension (approx. $50 \mathrm{~g}$ ) than a thinner, light thread (no more than $5 \mathrm{~g}$ of tension). For example, if the weight weighs 500 $\mathrm{g}$, the weaver can attach to it 10 warp threads that require a tension of $50 \mathrm{~g}$, but also 25 warp threads requiring a tension of $20 \mathrm{~g}$. If the weight weighs $200 \mathrm{~g}$, the weaver can attach to it 20 warp threads requiring $10 \mathrm{~g}$ tension or 10 warp threads requiring $20 \mathrm{~g}^{47}$ tension. Thus, it should be remembered that some weights could be "multifunctional", regardless of their weight. By changing type of the thread, it was possible to use them to produce different types of fabrics (Mårtensson et al. 2009, 378; Andersson Strand 2012, 210-212; cf. Andersson Strand 2018, 89-90).

\footnotetext{
${ }^{45}$ Although, of course, it cannot be excluded that some of the holes were pierced in the previously prepared clay disc. It is also difficult to resist the impression that the diameter of the holes of a large part of the circular weights corresponds to the diameter of the adult's thumb or index finger, which may also be related to the process of their production. Perhaps weights were also shaped around the stick.

${ }^{46}$ The range of the weight of conical or pyramidal specimens is very large and different researchers give different ranges (e.g. from $500 \mathrm{~g}$ to even $3.300 \mathrm{~g}$ ). Certainly among these weights, very heavy specimens are much more common, the weight of which far exceeds the weight of the heaviest circular specimens weighing about 530-620 g.

${ }_{47}$ The reconstruction carried out for $4 \mathrm{~cm}$ thick weights, weighing about $289 \mathrm{~g}$ each, which corresponds to the parameters of many circular weights is particularly interesting. According to calculations, such weights are suitable for threads requiring stresses between 15 and $20 \mathrm{~g}$, which gives 15 warp threads per weight. Assuming that the fabric is to be $60 \mathrm{~cm}$ long, there should be 15 weights in a row (Andersson Strand, Mannering 2011, 80-81).
} 
On the basis of the results of experiments, it can also be stated that attaching both: not enough, as well as too many warp threads to a single weight is unfavourable. Too many of them make weaving more difficult, too small number require the use of many weights. Thus, their thickness becomes very important, because only thin weights can be placed in a row corresponding to the total width of the fabric. It is best that the number of warp threads per weight is not lesser than 10 and larger than $30^{48}$, although it is more practical to use a maximum of 20 to 25 threads per weight (Andersson Strand 2012, 210-212). Of course, the number of warp threads per weight also depends on what fabric is wanted to obtain and with what thickness of yarn. These relationships can be summarized as follows: thick, open fabric + thick yarn $=$ heavy and thick weights; thick and dense fabric + thick yarn $=$ heavy, thin weights; open or thread fabric + thin yarn = light, thick weights; dense fabric + thin yarn with many threads per centimetre = light, thin weights (Mårtensson et al. 2009, 390).

Summing up, the most important parameters are weight and thickness the first one decides how many threads of a certain type can be attached to it, and the second one determines how close the threads will be arranged in the finished material. As already mentioned, the width of the finished fabric depends on both: the width of the initial edges and the total width of the weights in each row. Hence, it is most preferable that the weights hang close to each other or be slightly spaced. Therefore, the total width of the produced fabric would be equal or slightly larger than the sum of the thicknesses of all weights in a row. By translating this information into circular weights, it is easy to imagine that their shape, including, above all, the shape of the cross section, facilitated the use of more of them, and the weights themselves "cling" to each other much better than cone-shaped specimens. Thanks to this, it was possible to obtain a fabric with a much denser weave - both thick and delicate ${ }^{49}$ (Fig. 9, 11).

The aforementioned findings of weights in various shapes within one feature - circular and e.g. pyramidal, that can be used at the same time in one workshop, is also interesting. Perhaps, this was due to the desire to acquire a specific type of fabric or only the weight of the weights was taken into account, not their shape. In feature 17 from Herzprung, two pyramidal specimens were found on the edge of two rows of weights, another between the circular ones (Schuster 2004, Fig. 81). The location of the first of them may have been related to the way weaving the lateral edge (Fig. 9: 1). It cannot be excluded that the pyramidal specimens were used to increase the load on selected warp threads.

${ }^{48}$ In other tests, a range of 5-30 warp threads per weight is given (Mårtensson et al. 2009, 392-393).

${ }^{49}$ Its illustrated even better by the so-called discoidal weights, known from the Bronze Age ( $c f$. Ulanowska 2017, 2019). 
However on sites from the Roman Period and the early phase of the Migration Period, much more often various types of weights were discovered within different features, without creating a consistent set. It can be carefully assumed, that their diversity may also prove the diversity of weaving production and the diversity of produced fabrics.

In conclusion, the answer to the question whether circular weights could be parts of the weaving workshop is affirmative. But whether only and whether all of them?

\section{CIRCULAR WEIGHTS AS FISHNET SINKERS}

Except the not numerous fish remains, we have an extremely poor source base for reconstruction of fishing in the Roman Period and in the early phase of the Migration Period in Poland (cf. Makowiecki 2003, 103-105). This results mainly from the lack of preserved fishing tools or their elements or, as already mentioned, the inability to assign such function to objects made of clay, bone or metals, that preserved until this day, especially if they do not find analogies among the ethnographic materials. The presence of lakes or rivers near the settlements probably had a significance in transport ${ }^{50}$, but also undoubtedly contribute to the development of fishery. Some fishing methods, including, for example, hand fishing or stunning with a wooden peg, hammer ${ }^{51}$ or stone (cf. ZnamierowskaPrüfferowa 1933, 26; 1988, 24-26; Kłodnicki 2003, 377), for obvious reasons elude the attention of archaeologists. Taking into account the much better documented Medieval fishery and ethnographic analogies, it is known, that most fishing equipment was made of organic materials, including wood, bast or hemp, which have no chance to preserve until this day. Floats, that task was to keep the upper part of the fishnet on the surface, are the exceptions. Therefore, they had to be made of light materials that could float on the water, such as bark of deciduous trees - usually oak, rarely poplar or birch, and coniferous bark, mainly pine (Rulewicz 1994, 141-180 $)^{52}$. Interestingly, floats are well documented in Early Medieval fishery, and completely unknown (not recorded?) on sites from the Roman Period.

The least durable fishing gear includes nets, most likely woven from twisted plant fibres (flax, hemp, bast, roots $^{53}$ ). It cannot be excluded that some of the ropes

${ }^{50}$ Apart from Jordanes's message about the way the Goths reach today's Poland, their knowledge of the boats is indirectly demonstrated by the use of boats as coffins (Natuniewicz-Sekuła, Rein Seehusen 2010 - further literature there). It cannot be excluded that the boats were used to fishing.

${ }^{51}$ In winter fishing on the Narew River, a wooden hammer for stunning fish spotted under the ice was called "baśka" (Chętnik 1928, 133-134, fig. 89).

${ }^{52}$ Nowadays, floats are also formed of polystyrene (Gauda 1992, pl. XI: 19; Zamościński 2014, 144).

${ }^{53}$ In 1933, in the Druskininkai region (currently Lithuania), fishnets were woven by men and women of hemp, flax and cotton (Znamierowska-Prüfferowa 1933, 33). 
or cords used to set up or pull the nets were made of hide straps or horsehair (Rulewicz 1994, 137-141; cf. Znamierowska-Prüfferowa 1988, 91, 95).

The only items related to fishery of the Roman and Migrations Periods, that could preserve to our times, are those made of more durable materials, including primarily metal, antlers and clay. These include: fishing rod hooks, harpoons (cf. Rulewicz 1994, 99-137), and various types of piercing tools (cf. ZnamierowskaPrüfferowa 1957) and sinkers (in Polish grzęzidta, gręzy, grzęzy).

In the context of sinkers, it is important to recreate the role they could have played in fishery. Ethnographic research allows the reconstruction of various fishing methods. One of them is the so-called net fishing - both inland and sea. The types of fishnets relevant to this article include, but are not limited to: dragged, trammels, floating and drifting fishnets. K. Moszyński $(1967,108)$, due to their shape, divides them into wall-like (even or slightly concave) and snare (baggy) ${ }^{54}$.

Dragged nets should be included in the category of active fishnets, requiring direct human participation in the course of fishing, where fish have been gathered into the net by moving (pulling). One of the often used types of dragged fishnets were the so-called seines (in Polish niewód), occurring in different varieties and depending on the region having their own names (Moszyński 1967, 109, fig. 82; Znamierowska-Prüfferowa 1988, 56-71). The seine consisted of a baggy snare and two wings, spread out in the shape of a semicircle, directed the fish into the snare. Seine was attached to the upper rope, as well as the floats, while the weights to the drawnstring ${ }^{55}$ (Znamierowska-Prüfferowa 1932, 265; 1933, 30; cf. Zamościński 2014, 121-151).

Trammels, floating and drifting nets represent the category of passive fishing nets, because they were put on for a long time, and the fish caught on them without direct human intervention. In trammels, usually rectangular in shape, the upper part was attached to a rope with floats, while the lower part was loaded with weights (sinkers), usually also previously placed on a rope or cord. The ends of the ropes were anchored so that the net formed a vertical wall. Among the trammels, single-layer, two-layer or three-layer types are most common (Moszyński 1967, 11056). M. Znamierowska-Prüfferowa describes single-layer networks from the Druskininkai region (today's Lithuania) using the term "mesh" (in Polish siatka). Its lower part was placed with the use of

${ }^{54}$ Information on various types of fishnets, also used today, can be found in the following works: Kuklik 2014; Czochański 2016, 41-42; Zamościński 2014 and many others.Compare also Kotyza, Salač 1989, 61-63, fig. 5 .

${ }^{55}$ In traditional Kashubian fishery, various types of dragged nets, including seines, were bundled with reeds, grass, or, more rarely, pine branches. The "broom" created in this way paved the way for the weights and caused that they did not rub directly on the bottom, and the net itself could be easier to pull out (Zamościński 2014, 144).

${ }^{56}$ Cf. Znamierowska-Prüfferowa 1988, 71-76. 
stones "tied up in rags or an old mesh" or loaded with lead weights. From spring to winter fishermen set it up for the night (Znamierowska-Prüfferowa 1933, 29-30). Two- or three-layer trammels consisted of two or three adjacent walls. In the case of the last ones, the middle part was usually much denser and less tense than the lateral ones. Depending on the region, such fishnets were called drygubice, drygawice or trehubice (Znamierowska-Prüfferowa 1932, 264; 1933, 30; Moszyński 1967, 110-111). Interesting information can be found in work of M. Znamierowska-Prüfferowa, who says that in the upper part of this type of fishnet the floats made of bark were placed, while "clay stones" at the bottom. According to her, such a net was used in fishing on lakes. However, there was also a floating version, towed behind the boat, which was used in fishing on the Neman River (Znamierowska-Prüfferowa 1933, 30).

The type of fishnets that also use sinkers are cast nets (in Polish zarzutnia), sometimes also called thrown nets (in Polish narzutka or nakrywka) - parachutelike net made of a mesh with the edges loaded with weights. The smooth throw caused that the weights moving centrifugally opened the net, which fell like a "spread umbrella" to the bottom of the water, covering the fish. While pulling, the weights helped to close it and trap the fish inside (Moszyński 1967, 95-96; cf. Znamierowska-Prüfferowa 1932, 265; 1988, 77-81). Weights made of stones or other raw materials, depending on the region, could also have been used in fishing with a rope ${ }^{57}$ or using a push net (in Polish kryga) - a baggy net mounted on two poles after loading with stones tumbled to the bottom (ZnamierowskaPrüfferowa 1933, 28-29).

Unfortunately, I did not found any depictions of fishing in Roman or Greek iconography. Instead, they are known for Medieval and Modern Age iconography (e.g. Wyrwa 2012, fig. 11-17). From the point of view of this article, the most interesting is the scene depicting fishing with a net pulled simultanously from land and from a boat, imaged on a miniature from the legend of St. Hedwig of Silesia in the Lubin Code of 1353 (Fig. 12). It shows a net equipped with floats and weights (Rulewicz 1994, fig. 103; Wyrwa 2012, fig. 16; cf. also fig. 15 and 17).

Sinkers known from Medieval sites or used in traditional fishing could be made of stones, clay or lead. Stone weights were usually ordinary pebbles, often chipped on the sides, which allowed them to be more firmly tied with a rope. Sometimes, they also could have been wrapped in fabric. Weights made of clay usually looks like large spindle whorls (Rulewicz 1994, 185-190; cf. ZnamierowskaPrüfferowa 1988, 94). Sometimes they could had a slightly different shapes barrel, cylindrical, segmented (Zbierski 1959, 108, pl. I: 2; Sikorski 2000).

${ }^{57}$ During fishing on the Nemen and Bug Rivers, shorter strings finished with hooks (approximately every 2 meters) were tied to the rope and fastened at the ends using stones - weights. Such a rope was set for the night (Znamierowska-Prüfferowa 1932, 263; 1933, 26; cf. 1988, 39-42). It was also used for fishing on the Narew (Chętnik 1911, 60). 


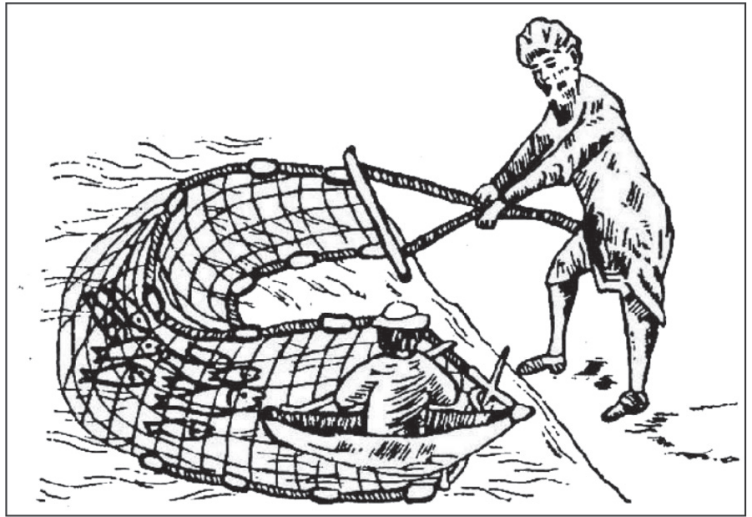

Fig. 12. Fishing with a net on miniature from the legend of Saint Hedwig of Silesia in the Lubin Code of 1353. After: Wyrwa 2012

The basic question in the context of this article is whether clay circular weights from the Roman Period and the early phase of the Migration Period could have been used to load the fishnet, i.e. whether they could have play the role of sinkers. This issue should be considered in such categories as: raw material, method and accuracy of production, as well as weight; place and context of discovery and accompanying artefacts. For the already mentioned reasons, it is also necessary to make use of Medieval or ethnographic analogies.

Raw material, accuracy and method of production, weight

The most common argument of opponents of combining clay circular weights with fishing is the material of which they were made. In order to play the role of fishnet weights, they had to be well fired. Specimens poorly fired or only dried in the sun could simply fall apart in contact with water. However, circular weights from Puławy-Włostowice and Nieszawa Kolonia seem to meet the criteria of the fishnet sinkers. They are well fired and hard. Nevertheless, it shouldn't be forgot, that some of the specimens from Nieszawa Kolonia were discovered in hearths, hence they may have been fired somewhat "secondary". In the case of weights from Dobre we are dealing with a quite amazing situation. One of them has preserved to this day and gives the impression of being resistant to water; the others were to be unfired and fall apart during exploration ${ }^{58}$ (Fig. 2).

For obvious reasons, I did not risk putting the circular weights from PuławyWłostowice into the water. However, thanks to the observations made during

${ }^{58}$ Without denying the accuracy of the observations made by the explorers, this could also be influenced by post-depositional factors. Some explanation, on the verge of speculation, may also be the statement that the specimens that fell apart were a blanks, which for unknown reasons were not fired. 
washing the fragments of vascular ceramics or spindle whorls, I can say that they can withstand contact with water without any problems. What's more, the weight of clay items slightly increases after soaking, and after drying they do not lose their form. Recalling ethnographic analogies, it should be certainly stated that the raw material of which circular weights were made does not negate the possibility of using them as the fishnet sinkers. However, the basic criterion for assigning them such a function is their good firing, thanks to which they withstand contact with water, but also repeated drying and soaking in water.

As already mentioned, almost all circular weights from the Roman Period and the early phase of the Migration Period have a very large holes. Considering them as weights for the fishnets, this fact seems to find a very good explanation. The large hole allowed for a smooth threading of the thick rope, which was then attached to the bottom rope of the net (cf. Rulewicz 1994, 186).

From the point of view of the use of the circular weights as a sinkers, their round shape did not have much significance, unlike their weight. Certainly it was enough to load the fishnet. At least several weights were used for this purpose, and their number was determined by the size of the net. Thus, the more weights, the greater total weight. The materials of which the nets were made should also be in mind. Plant fibres - due to twisting, as well as the very structure of the net were quite durable, but still they were organic materials. It was also necessary to maintain a balance between the number of floats and the method of net's floating, as well as the number and weight of sinkers. Too few of the first, with too much weight of the second could cause the net to sink. In addition, the number and weight of sinkers and the number of floats could be changed, which allowed the fishnet to be located at the desired depth (Rulewicz 1994, 184; Zamościński 2014, 162). Estimating the configuration of floats and weights in Roman Period nets is impossible. Ethnographic materials, including preserved nets, shed some light on this problem. In one of them (drygubica), the floats are located at a distance of $1.5 \mathrm{~m}$, and lead and stone weights, sometimes wrapped in cloths, at intervals of $45-50 \mathrm{~cm}$ (Rulewicz 1994, 201).

In the context of the weight of the sinkers, the function of a weight from Dobre, made of marl rock and preserved in about $1 / 2$, should also considered. It weighs $152 \mathrm{~g}$, i.e. the whole specimen weighed about $300 \mathrm{~g}$ - comparable to a clay circular weight from this site ( $287 \mathrm{~g}$, with numerous defects). It cannot be excluded, that it was also used as a net weight (or as a weaving weight). An interesting analogy is the sinker discovered within Modern Age layers in Kazimierz Dolny, Puławy District, made of local, "Kazimierz marl rock" with a length of about $13.5 \mathrm{~cm}$ and a hole diameter of $1 \mathrm{~cm}$. The advantage of this raw material is softness and ease of processing, especially after soaking ${ }^{59}$. Unfortunately, I do not know the weight of

${ }^{59}$ K. Tajer, Zamek nad Wisła - http://www.smakizpolski.com.pl/zamek-wisla/ [access 30.01.2020]. 
the specimen. Limestone, however, are very light, which would seem to contradict the recognition of items made of them as a sinkers. It should be remembered, however, that this marl rock perfectly absorbs water, which directly translates into a significant increase in its weight ${ }^{60}$. Thus, perhaps a weight made of marl rock from Dobre could have also been used as a sinker. Artefacts made of this raw material, although of other shapes, were also discovered in Nieszawa Kolonia. They are interpreted as fishnet sinkers (Stasiak-Cyran 2016, 78) (Fig. 13).
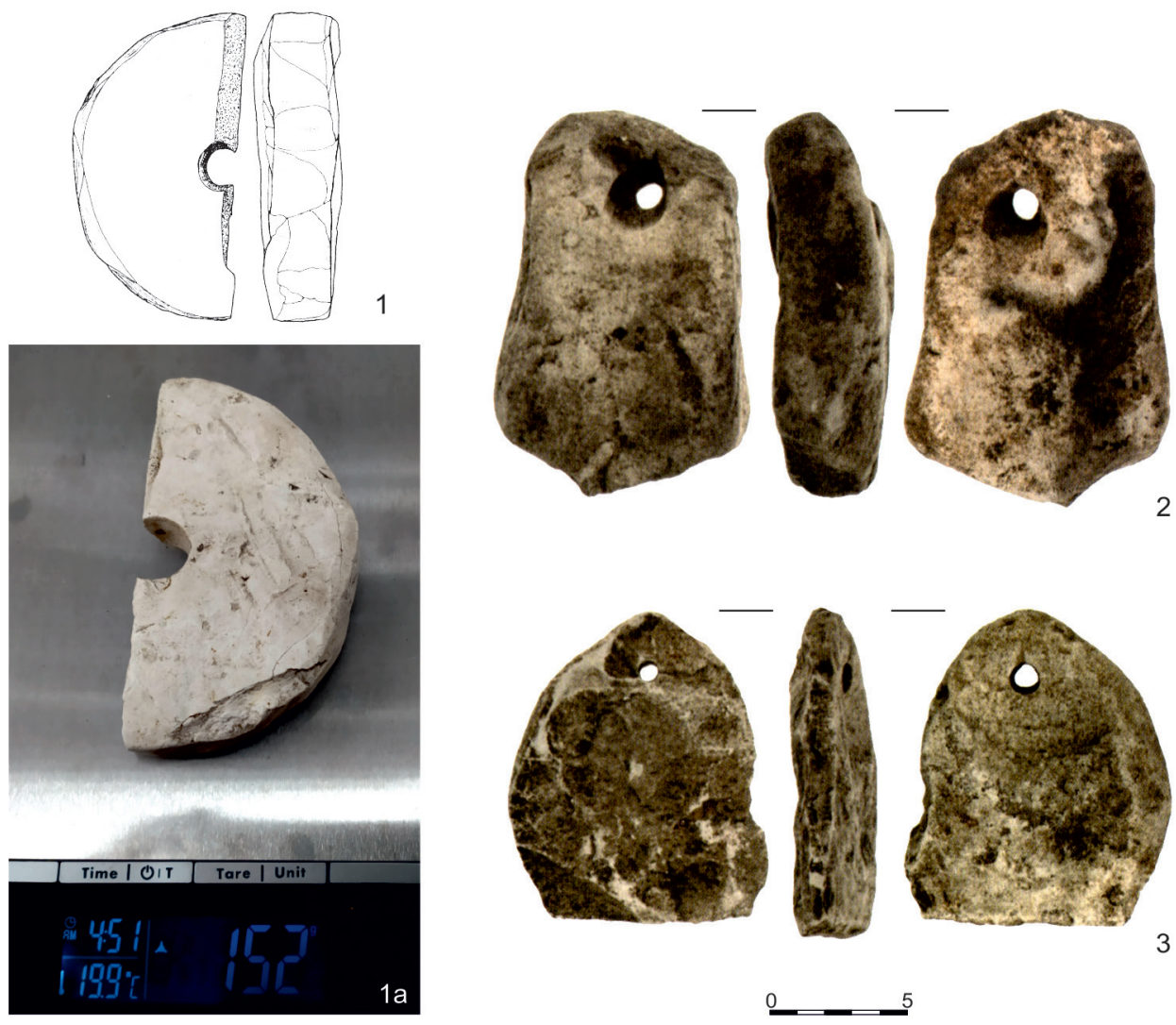

Fig. 13. Dobre - weight made of marl rock (1) and Nieszawa Kolonia - sinkers for the fishnets made of the marl rock (2-3). Photo: M. Stasiak-Cyran (1a). After: Kokowski 1991 (1),

Stasiak-Cyran 2016 (2-3)

${ }^{60} \mathrm{I}$ know from experience gained during the work in Ulów that fragments of rock found in the fills of features, including mainly Modern ones, soaked water very quickly during washing, and then dried out for a long time. 
Place and context of discovery and accompanying artefacts

I have already described the place and context of discovery of the circular weights in sites dated back to the Roman Period and the early phase of the Migration Period in the context of interpreting them as elements of weaving workshops. Occurrence of single specimens in hearths or in residential features almost with equal probability can indicate to the remains of a weaving workshop, as well as to drying or repairing the fishnets.

The location of sites in Dobre, Nieszawa Kolonia, Oronne and PuławyWłostowice is more puzzling. As already mentioned, they all are located on the right bank of the Vistula, with a short distance from each other and from the Vistula itself, some of them additionally on small Vistula tributaries. Indirectly, this fact may indicate the interpretation of discovered circular weights as sinkers for fishing nets. In the Roman Period, Vistula was a wild and highly meandering river, and the lack of its regulation certainly - at least periodically - caused the formation of large floodwaters ( $c f$. Reder 2018). This favoured fishing, both on the river and in its backwaters. Of course, the opponents of this hypothesis will argue, that the condition for the functioning of all settlements was the availability of water and all of them are located near various watercourses or lakes. It is difficult to disagree with this argument. It is interesting, however, that in the Przeworsk culture settlements located on the left bank of the Vistula, such as Jakuszowice, Kazimierza Wielka District or Złota, Sandomierz District, in the case of the last one also in a very short distance from the Vistula, circular weights and other items indicating fishing did not occur (Kaczanowski, Rodzińska-Nowak 2010, 242; Urbaniak 2008 ${ }^{61}$ ). Perhaps one can risk a statement about the existence of some form of the local economy within sites located on the right bank of the Vistula.

Analysing the map of the spread of circular weights dated back to the Roman Period or the early phase of the Migration Period, it can be noticed that they were found within sites located in lowland areas and on the edges of plateaus, in a very short distance from water reservoirs and additionally in areas with a highly developed river network (Fig. 1).

The possibility of relating circular weights from the "Vistula" sites of the Przeworsk culture with fishing, is much more pointed by the presence of other material traces of this branch of economy within the sites or in this settlement zone. They are best documented in the settlement of Nieszawa Kolonia, where numerous fish remains were discovered, including fish scales and a series of tools that could be used in fishing. Among them, in addition to the analysed circular

${ }^{61}$ Only fragments of seven weaving weights, most probably conical, have been discovered at the site in Złota (Urbaniak 2008, 17). 
weights and the two mentioned above sinkers made of marl rock, items that could have been used to weave nets, hooks and harpoons were discovered (StasiakCyran 1999, 127-128, fig. 3: 1-3, 6, 7; 2004, 93-95; 2016, 44, 77, pl. CI: 10). Harpoons - small, iron points with barbs are also known from other "Vistula" sites of Przeworsk culture, including Puławy-Włostowice (Niezabitowska-Wiśniewska 2018a, 454, 484-485, fig. 22: ZL, pl. XLII: ZL. 9) or Oblin, Garwolin District (3 specimens - Czarnecka 2007, 20, 22, 54, 84, pl. XLI: 4, XLVII: 17, CXCI: 5).

In addition to already described ethnographic sources, finds originating from other areas and other periods indicates to the possibility of interpreting at least some of the circular weights as sinkers. At Medieval sites such as Wolin, Szczecin or Gdańsk, clay circular weights are often found in layers along with the fishnet floats (Rulewicz 1994, 189; cf. Kowalska 2015, 122) ${ }^{62}$ (Fig. 8). Circular weights sinds are also extremely interesting during underwater research, sometimes in the vicinity of former bridge crossings. In these cases, the place of discovery confirms the possibility of using them as a sinkers. They were discovered in places like: Lake Jeziorak in the area of the bridge crossing from the Wielka Zuława island to the North (Ilawa, site 33) (Popek et al. 2013, 376, fig. 6; Kobylińska 2017, 345, fig. 31); Lubniewice, Sulęcin District, site 10 (Chudziak et al. 2016, 108, fig. 99); Łasin, Grudziadz District, site 2 (Chudziak et al. 2011, 106, fig. 80: a-b); Mragowo, District loco, site 16 (Chudziak et al. 2011, 130, fig. 103: e-f); Nętno, Drawsko Pomorskie District, site 38 (Chudziak et al. 2016, 149, fig. 164: h); Nowy Dworek, Świebodzin District, site 27 (Chudziak et al. 2016, 185, fig. 192: b-e); Radomno Lake, Nowe Miasto Lubawskie District (Grażawski 2013, 129, fig. 6). Dating of these artefacts is very difficult due to the context of the discovery. However, most often they are related with the Middle Ages or less often with the Modern Period. Some of the mentioned weights are clearly two-conical in cross section, which makes them similar to spindle whorls; others are strongly flattened or semi-circular (Fig. 14). The diameter of most specimens oscillate between 9.5 and $11.5 \mathrm{~cm}$, and the known weight of two specimens is 163.30 and $219.19 \mathrm{~g}$. Thus, all metric parameters of Medieval or Modern Age sinkers are similar to the Roman Period and the early phase of the Migration Period weights.

${ }^{62}$ A large series of circular weights originate from Janów Pomorski (Truso), where they were found in buildings in the port, as well as in the central zone. They are interpreted as weaving weights, which, especially in the context of the place where they were found in the first of these zones, may be somewhat wondering (Auch et al. 2012, 100-101, fig. 35-36,pl. 27: 8; 28: 1- 2; Jagodziński 2010, 184, fig. 298-301; 2015, 74-75, fig. 60). 


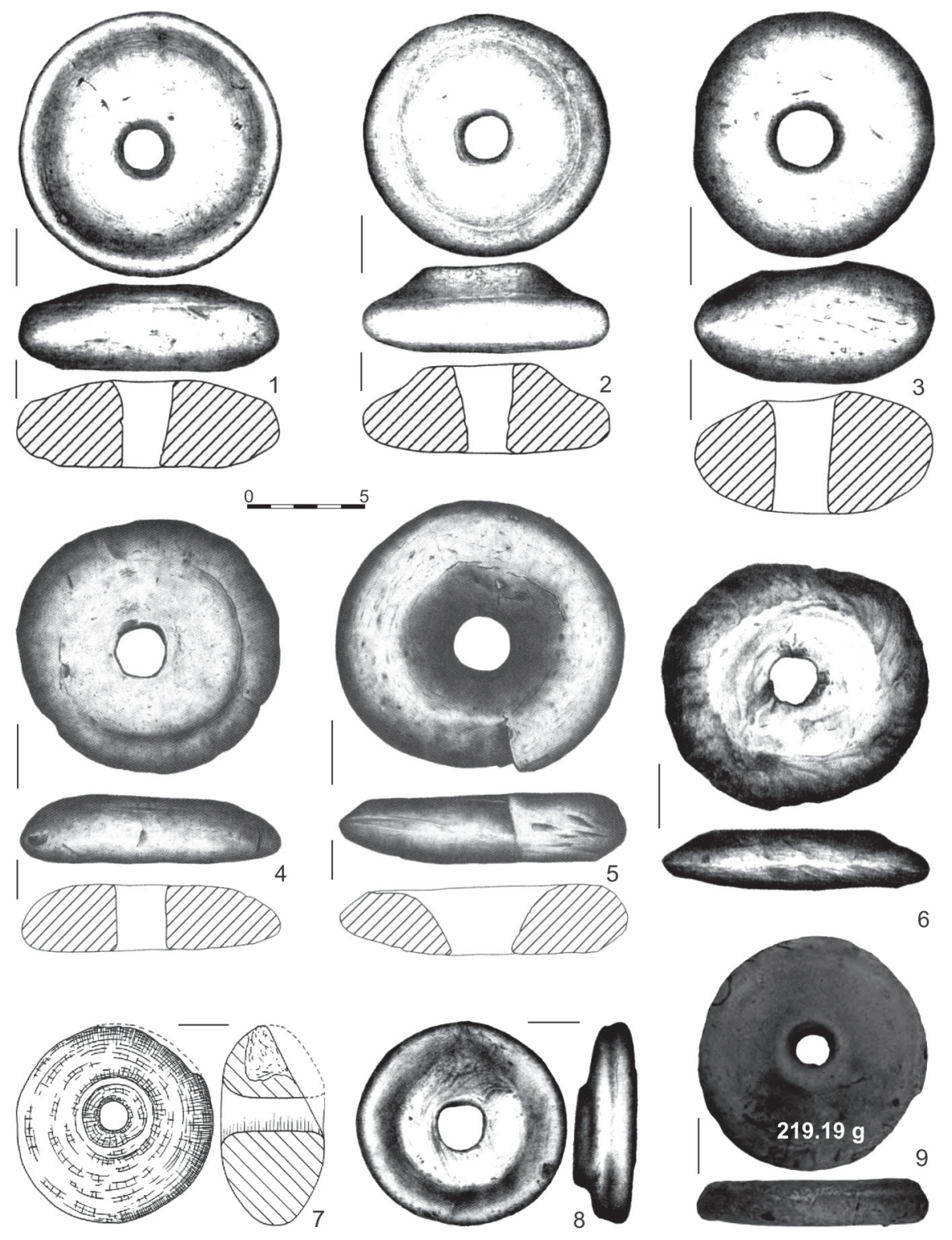

Fig. 14. Circular weights discovered during the underwater excavations - the selection.

1-2 - Nowy Dworek, 3 - Lubniewice, 4-5 - Łasin, 6, 8 - Mragowo, 7 - Jezioro Chociszewskie, 9 - Lake Jeziorak (Iława, site 33). After: Chudziak et al. 2016 (1-3), Chudziak et al. 2011 (4-6, 8), Chachlikowski et al. 2013 (7), Kobylińska 2017 (9) 


\section{IF NOT WEAVING WEIGHTS AND NOT SINKERS, THEN WHAT?}

An alternative to the already presented functions of circular weights, although the least likely, is to consider them as scales weights. This hypothesis can be indirectly substantiated by their diverse weight and - above all - the marks placed on some of them - most often engraved or imprinted, including in the form of point dents occurring in various numbers and arrangements (e.g. Polanowice, Herzsprung, Lipianki) $^{63}$ (Fig. 15). As J. Schuster noted, it is unlikely that the order of placing the weights in the weaving workshop is marked in this way. Their disc shape and method of attaching to the warp threads, causing one specimen to adhere to the others, effectively obscured the marks placed on them (Schuster 2004, 179). Only the markings preserved on the side walls of some conical or pyramidal weights could be visible during weaving, although in this case we are unable to determine their functional meaning (Słomska 2015, 454). The purpose of circular weights marking is also difficult to justify in the context of being interpreted as a sinkers. Some markings may have been a property marks. Of course, these symbols can also be interpreted as magical-ritual auguries, which - in my opinion - only confirms our helplessness in the interpretation of their real meaning.

\section{SUMMARY}

The universality of the circular weights forms and the simplicity of their production result in an extremely wide period of occurrence of this type of artefacts. Their presence, with varying intensity, in different periods and in different parts of Europe, from the Neolithic to Modern Age, denies the possibility of "transferring" tradition and "inheriting" the skill of producing these items ${ }^{64}$. In this light, interpreting them as foreign elements in the Przeworsk culture or brought in by the way of exchange, or being imitations of specimens from the Luboszyce culture - as D. Żychliński sees it from materials from Greater Poland $(2011,167)$ - does not seems to be justified ( $c f$. Schuster 2004, 179). In addition, weights from some of the Przeworsk and Wielbark culture sites originate from assemblages dated much earlier than the period of their dissemination in the Luboszyce culture. For these types of items, it is more likely that the function determined their shape. Thus, the differences visible in the shapes of particular specimens of circular

${ }^{63}$ Similar marks also appear on some of the Early Medieval weights (e.g. Dalem, MidlumNorthum, Feddersen Wierde, Lkr. Cuxhaven - Zimmermann 1982, fig. 12: 16-17, 19; 13: 7, 15-20, 23, 27, 28; 14: C; Janów Pomorski - Jagodziński 2010) (Fig. 15).

${ }^{64}$ This note also applies to weights of other shapes, including conical and pyramidal ones, which, like circullar weights, are found from the Neolithic period to the Early Middle Ages in various parts of Europe (e.g. Chmielewski 2009, 175-186; Stahlhofen 1978; cf. also Słomska 2019, 91-93 - type 1 there). 


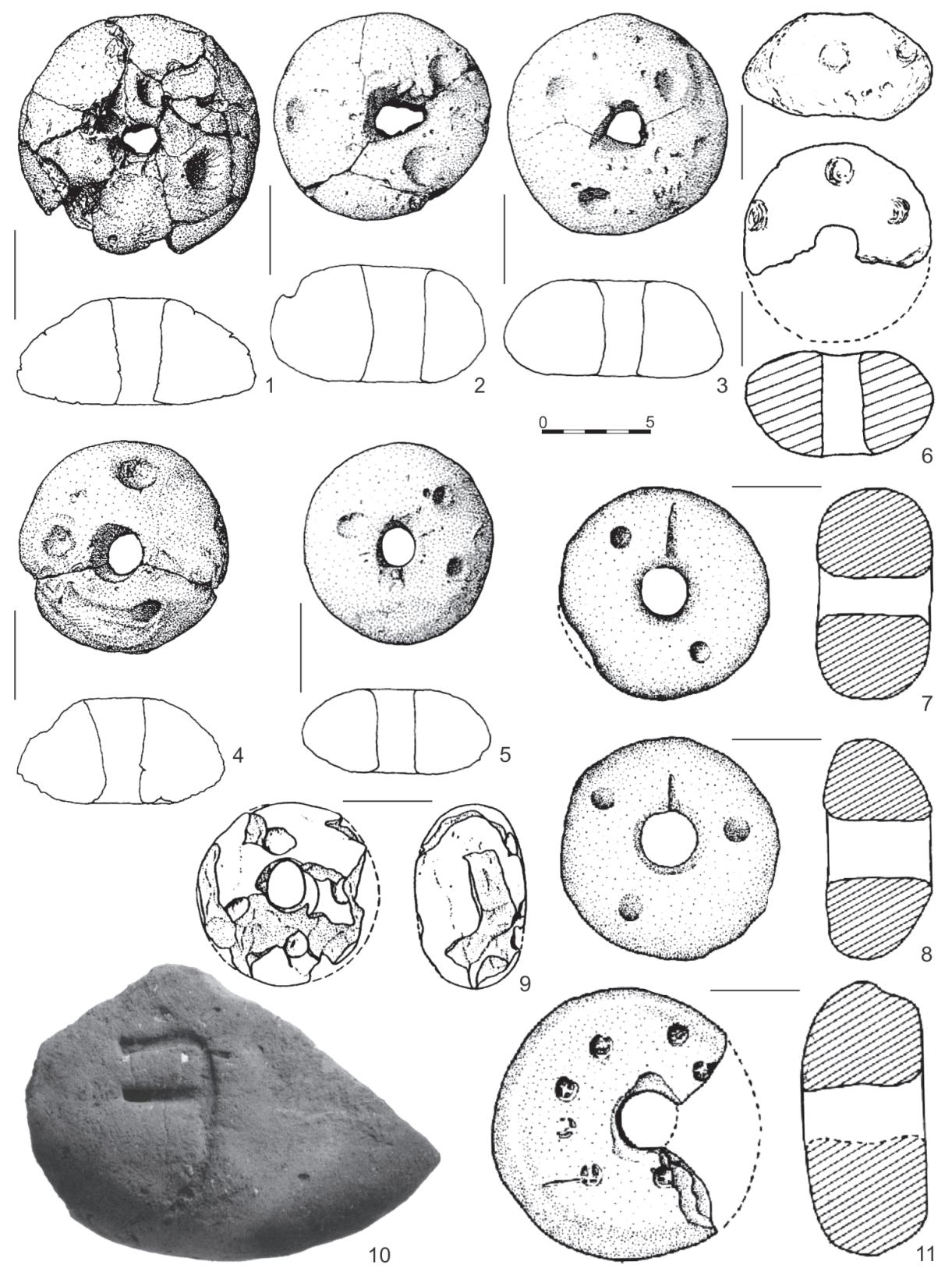

Fig. 15. Marks on circular weights. Luboszyce culture / Elbe circle (1-6, 9). Early Middle Ages (7-8, 10-11). 1-5 - Herzsprung, 6 - Polanowice, 7-8 - Dalem, 9 - Göritz, 10 - Janów Pomorski (Truso), 11 - Midlum-Northum. After: Schuster 2004 (1-5), Domański 2010 (6), Zimmermann 1982 (7-8, 11), Jagodziński 2010 (10). 10 - without scale, diameter about $15 \mathrm{~cm}$ 
weights or the preference for a certain pattern of their production in a given area and in a given time period, seem to be nothing but a manifestation of local tastes or skills. However, it should be emphasized, that circular weights, regardless of the period or area of occurrence, have very similar metric parameters.

According to the analysis, circular weights, depending on the circumstances, could be used both in weaving workshops, as well as a sinkers for various types of fishing nets. Currently we are not able to confidently determine the function of particular specimens. We can only carefully assume that weights with a visible groove, running from their hole towards the edge were used as weaving weights. Perhaps these grooves were created during the time-consuming process of weaving, as a result of the gradual "encroaching" of the thread forming the loop to which the warp threads were attached. The weights for fishing nets were intended to sink to the bottom of the water. In addition, they had to be well fired. Thus, it is unlikely that a cord or threads of the fishnet could carve out such a trace, even when dragging or pulling the nets out of the water.

Contrary to appearances, which have not been noticed so far, fishing and weaving have a lot in common. In both these areas of economy, natural raw materials, such as flax and hemp were used - in weaving for fabric production, in fishery - for weaving nets. Threads, regardless of their subsequent use, most likely were produced in the same way. Therefore, since the spindle whorls were perfect for spinning, why not to make a larger specimens and use them as weaving weights? These, in turn, since they worked well when loading warp threads, why not used them to load fishing nets made of twisted threads? Interesting information is also found in the work of M. Znamierowska-Prüfferowa. She described the network used on the Bug River and called "wata". It was a kind of small seine with two wings and a snare. It was made "of hemp, thick canvas, woven on looms" (Znamierowska-Prüfferowa 1932, 264-265, fig. 224). Hence, it cannot be ruled out that even in prehistory fabrics could have been used as nets or their elements. Perhaps our helplessness in interpreting the functions of some items results from the desire to obtain a clear answer. However, we forget that most often the simplest solutions are the best, and the need is the mother of the invention.

\section{REFERENCES}

Andersson E.

1999 The common thread. Textile Production during the Late Iron Age - Viking Age, University of Lund. Institute of Archaeology, Report Series, vol. 67, Lund.

Andersson Strand E.

2011 Tools and Textiles Production and Organisation in Birka and Hedeby, [in:] Viking Settlements and Viking Society. Papers from the Proceedings of the 
Sixteenth Viking Congress, Reykjavik and Reykholt, 16th-23rd August 2009, S. Sigmundsson (ed.), Reykjavík, p. 1-17.

2012 From Spindle Whorls and Loom Weights to Fabrics in the Bronze Age Aegean and Eastern Mediterranean, [in:] Kosmos. Jewellery, adornment and textiles in the Aegean Bronze Age. Proceedings of the 13th International Aegean Conference, University of Copenhagen, Danish National Research Foundation's Centre for Textile Research, 21-26 April 2010, M.-L. Nosch, R. Laffineur (eds.), Aegaeum 33, Leuven - Liege, p. 207-212.

2018 Experimental Textile Archaeology - A Link to the Past, [in:] Traditional Textile Craft. An intangible cultural heritage?, C. Ebert, S. Frisch, M. Harlow, E. Andersson Strand, L. Bjerregaard (eds.), Copenhagen, p. 77-92.

Andersson Strand E., Heller S.-G.

2017 Production and Distribution, [in:] A cultural history of dress and fasion in the Medieval Age, S.-G. Heller (ed.), London - Oxford - New York -New Delhi Sydney, p. 29-52.

Andersson Strand E., Mannering U.

2011 Textile Production in the Late Roman Iron Age a Case Study of Textile Production in Vorbasse, Denmark, [in:] Arkceologi i Slesvig / Archäologie in Schleswig. Sonderband „Det 61. Internationale Sachsensymposion 2010“ Haderslev, Danmark, L. Boye et al. (eds.), Neumünster, p. 77-84.

Antosik Ł., Słomska J.

2018 Early Medieval looms in Poland in the light of archaeological finds, Fasciculi Archaeologiae Historicae 31, p. 115-124.

Auch M., Bogucki M., Trzeciecki M.

2012 Osadnictwo wczesnośredniowieczne na stanowisku Janów Pomorski 1, [in:] Janów Pomorski, stan. 1. Wyniki ratowniczych badań archeologicznych w latach 2007-2008, vol. I: 2. Od późnego okresu wędrówek ludów do nowożytności, M. Bogucki, B. Jurkiewicz (eds.), Elblag, p. 23-232.

Banasiewicz E.

1988 Osada z okresu wptywów rzymskich w Hrubieszowie-Podgórzu, st. 1a, woj. zamojskie, badania 1984 roku (doniesienia wstęne), [in:] Prace i Materiaty Zamojskie, Zamość p. 49-92.

1989 Kompleks osadniczy grupy mastomęckiej $w$ Hrubieszowie-Podgórzu $w$ woj. zamojskim, [in:] Kultura wielbarska $w$ mtodszym okresie rzymskim (materiaty $z$ konferencji), vol. II, J. Gurba, A. Kokowski (eds.), Lublin, p. 47-61.

Barska K.

2001 Warsztat tkacki z Ożarowa, Z Otchłani Wieków 56/1-2, p. 69-73.

2004 The Roman Period warp-weighted loom from Ożarów Mazowiecki, Poland, [in:] Priceless invention of humanity - textiles, Acta Archaeologica Lodziensia 50/1, p. $45-54$.

Bednarczyk J.

$1987 Z$ badań sanktuarium $i$ osady ludności kultury przeworskiej $w$ Inowroctawiu, woj. Bydgoszcz, st. 95, Sprawozdania Archeologiczne XXXIX, p. 201-221.

2000 Życiecodzienne wokresierzymskim, [in:] Gazociag pełen skarbów archeologicznych. Katalog wystawy zorganizowanej pod patronatem Ministra Kultury i Sztuki Rzeczypospolitej Polskiej Pani Joanny Wnuk-Nazarowej i Sekretarza Generalnego Rady Europy Pana Daniela Tarschysa, M. Chłodnicki, L. Krzyżaniak (eds.), Poznań, p. 73-98. 
Berg-Hobohm S.

2004 Die germanische Siedlung Göritz, Lkr. Oberspreewald-Lausitz, Forschungen zur Archäologie im Land Brandenburg, vol. 7, Wünsdorf.

Burchard B., Eker A.

1964 Osada kultury czasz lejowatych w Ksiażnicach Wielkich, pow. Kazimierza Wielka, [in:] Studia i materiaty do badań nad neolitem Małopolski, S. Nosek (ed.), Prace Komisji Archeologicznej 4, Wrocław - Warszawa - Kraków, p. 191-327.

Chachlikowski P., Dębski A., Krzepkowski M., Romańska A., Sobkowiak-Tabaka I. 2013 Katalog zbiorów archeologicznych Stanisława Pijanowskiego, [in:] Zabytki archeologiczne ze zbiorów inż. Stanisława Pijanowskiego z Gtuchej Puszczy, M. Krzepkowski, M. Kranc (eds.),Wagrowiec, p. 99-219.

Chętnik A.

1911 Rybołówstwo na Narwi, Ziemia 2/4, p. 59-61.

1928 Rybołówstwo zimowe nad Narwia, Ziemia 13/9, p. 133-135.

Chmielewski T.J.

2009 Po nitce do ktębka... O przędzalnictwie i tkactwie mtodszej epoki kamienia w Europie Środkowej, Warszawa.

Chudziak W., Kaźmierczak R., Niegowski J.

2011 Podwodne dziedzictwo archeologiczne Polski. Katalog stanowisk (badania 20062009), Torun.

2016 Podwodne dziedzictwo archeologiczne Polski. Katalog stanowisk (badania 20112015), Torun.

Czarnecka K.

2007 Oblin. Ein Gräberfeld der Przeworsk-Kultur in Südmasowien, Monumenta Archaeologica Barbarica XIII, R. Madyda-Legutko (ed.), Warszawa.

2012 Materiaty $z$ wielokulturowej osady $i$ cmentarzyska kultury przeworskiej na stanowisku 1 i 2 w Oronnem, pow. garwoliński, Wiadomości Archeologiczne LXIII, p. 115-144.

Czochański H.

2016 Tradycyjne narzędzia rybotówstwa śródladowego $w$ zbiorach Białostockiego Muzeum Wsi, Rocznik Białostocki 20, p. 35-50.

Dąbrowski K.

1958 Osadnictwo $z$ okresów późnolateńskiego $i$ rzymskiego na stanowisku $1 \mathrm{w}$ Piwonicach, pow. Kalisz, Materiały Starożytne 4, p. 7-90.

Dębski A., Krzepkowski M.

2013 Zabytki średniowieczne i nowożytne, [in:] Zabytki archeologiczne ze zbiorów inż. Stanistawa Pijanowskiego z Gtuchej Puszczy, M. Krzepkowski, M. Kranc (eds.), Wagrowiec, p. 77-81.

Dolinescu-Ferche S.

1974 Aşezări din secolele III şi VI e.n. în sud-vestul Munteniei. Cercetările de la Dulceanca, Biblioteca de Arheologie XXIV, Bucureşti.

Domański G.

1979 Kultura luboszycka między Eabq a Odra w II-IV wieku, Wrocław - Warszawa Kraków - Gdańsk.

1985 Prace wykopaliskowe na osadzie $z$ okresu wptywów rzymskich $w$ Jazowie, gmina Gubin, woj. zielonogórskie, na stanowisku 3, Ślaskie Sprawozdania Archeologiczne XXVI, p. 47-49.

2004 Luboszyce, pow. krośnieński, woj. lubuskie, stan. 4, [in:] Wandalowie - strażni- 
cy bursztynowego szlaku. Katalog wystawy w Państwowym Muzeum Archeologicznym, J. Andrzejowski, A. Kokowski. Ch. Leiber (eds.), Lublin - Warszawa, p. 279.

2010 Dorzecze dolnej Nysy Łużyckiej u schytku starożytności, Wrocław.

Feugère M.

2009 Métiers à tisser antiques d'Asie Mineure, Instrumentum 30, p. 22-24.

Gauda A.

1992 Tradycyjne rybołówstwo na Pojezierzu Łęczyńsko-Wtodawskim, Lublin.

Geisler H.

1976 Ein Gerätdepot der späten römischen Kaiserzeit aus Breslack, Kr. Eisenhüttenstadt, Veröffentlichungen des Museums für Ur- und Frügeschichte Potsdam 10, p. 141-158.

Gołębiewski A.

2003 Wstepne wyniki badań osady z okresu wpływów rzymskich w Stanistawiu, gmina Tczew, stanowisko 37, [in:] XIII sesja pomorzoznawcza, vol. 1. Od epoki kamienia do okresu rzymskiego, M. Fudziński, H. Paner (eds.), Gdańsk, Grążawski K. p. 201-210.

1988 Średniowieczny gródek rycerski w Bachotku na Ziemi Chetmińskiej w świetle badań archeologicznych, Sprawozdania Archeologiczne XL, p. 317-341.

2013 Sprawozdanie $z$ archeologicznych badan weryfikacyjnych przeprowadzonych w Radomnie w 2011 r., [in:] XVIII sesja pomorzoznawcza. Vol. 1. Od epoki kamienia do wczesnego średniowiecza. Materiaty z konferencji 16-18 listopada 2011, E. Fudzińska (ed.), Malbork, p. 125-131.

Hoffmann M.

1974 The Warp-Weighted Loom, Studies in the History and Technology of an Ancient Implement, Oslo - Bergen - Tromsø.

Jagodziński M.F.

2010 Truso. Między Weonodlandem a Witlandem, Elblag.

2015 Truso - legenda Battyku / the legend of the Baltic Sea. Katalog wystawy, Elblag.

Kaczanowski P., Rodzińska-Nowak J.

2010 Gospodarka mieszkańców osady kultury przeworskiej w Jakuszowicach, [in:] Archeológia Barbarov 2009. Hospodárstvo Germánov. Sídliskové a ekonomické štruktúry od neskorej doby laténskej po včasný stredovek, J. Beljak, G. Březinová, V. Varsik (eds.), Archaeologica Slovaca Monographiae. Communicationes X, Nitra, p. 239-246.

Kaczmarek Z.

$2012 O$ warsztatach tkackich $w$ starożytnym Rzymie stów kilka, Studia Europaea Gnesnensia 5, p. 183-202.

2013 Tkactwo $w$ relacjach kulturowych Cesarstwa Rzymskiego z Barbaricum (IIII wiek n.e.), Rozprawa doktorska, Poznań, https://repozytorium.amu.edu. pl/bitstream/10593/7808/1/rozprawa\%20doktorska\%20Z.\%20Kaczmarek.pdf [Access 12.02.2020].

Kalka P.

2005 Osada ludności kultury wielbarskiej w Klonówce, gm. Starogard Gdański, stan. 47 (na trasie autostrady A1 numer 140). Badania w latach 2000-2003, [in:] XIV sesja pomorzoznawcza, vol. 1. Od epoki kamienia do okresu rzymskiego, M. Fudziński, H. Paner (eds.), Gdańsk, p. 441-470. 
Kaszewska E., Kaszewski Z.

1963 Toporów 1, Distr. de Wieluń, Dép. de Łódź, Inventaria Archaeologica, PL, X, Pl. 56.

Kłodnicki Z.

2003 Przyrodnicze $i$ kulturowe uwarunkowania tradycyjnego rybołówstwa śródladowego w Polsce, [in:] Woda w przestrzeni przyrodniczej i kulturowej. Prace Komisji Krajobrazu Kulturowego II, Sosnowiec, p. 375-381.

Kobylińska U.

2017 Iława, st. 33 - Wielka Żuława, gmina Iława, powiat iławski. Znaleziska, [in:] Katalog grodzisk Warmii i Mazur, tom I, Z. Kobyliński (ed.), Warszawa, p. 324-347.

Kokowski, A.

1991 Lubelszczyzna $w$ młodszym okresie przedrzymskim $i$ w okresie rzymskim, Lublin.

2004 Burgundowie czylikultura luboszycka, [in:] Wandalowie-strażnicy bursztynowego szlaku. Katalog wystawy w Państwowym Muzeum Archeologicznym, J. Andrzejowski, A. Kokowski. Ch. Leiber (eds.), Lublin - Warszawa, p. 263-269.

Kotyza O., Salač V.

1989 Rybářská závaží z polykulturního sídliště v Lovosicích-Resslově ulici, Vlastivědný sborník Litoměřicko 24 (1988), p. 55-71.

Kowalska A.B.

2015 Rybyi ludzie. Udziat rybołówstwa wżyciu gospodarczym wczesnośredniowiecznego Szczecina na podstawie źródet archeologicznych, [in:] O rzece i wodzie $w$ życiu codziennym człowieka średniowiecza, S. Moździoch, K. Chrzan (eds.), Spotkania Bytomskie VIII, Wrocław, p. 113-126.

Kuklik M.

2014 Narzędzia i metody połowów $w$ rybołówstwie przybrzeżnym, [in:] Jem jô rëbôk... Rybołówstwo na Kaszubach - tradycja i wspótczesność, A. Kwaśniewska (ed.), Wieżyca, p. 271-312.

Leube A.

1975 Die römische Kaiserzeit im Oder-Spree-Gebiet, Veröffentlichungen des Museums für Ur- und Frühgeschichte Potsdam 9, Berlin.

Easzczewska T.

1966 Pradzieje włókiennictwa, [in:] Zarys historii włókiennictwa na ziemiach polskich do końca XVIII wieku, J. Kamińska, I. Turnau (eds.), Wrocław - Warszawa Kraków, p. 21-53.

Łuczkiewicz P.

2008 Sobieszyn, Fsdt. 14, pow. Ryki, wojw. lubelskie. Eine Siedlung der PrzeworskKultur aus der jüngeren vorrömischen Eisenzeit und der frührömischen Kaiserzeit in Ostpolen, [in:] Barbarská sídliště. Chronologické aspekty jejich vývoje ve světle nových archeologických výzkumů, E. Drobrejar, B. Komoróczy, D. Vachůtová, D. (eds.), Brno, p. 259-278.

Machajewski H.

1995 Osadnictwo $z$ okresu przedrzymskiego, rzymskiego $i$ wędrówek ludów na stanowisku 1 w Gtuszynie, woj. stupskie, Materiały Zachodniopomorskie XLI, p. 39-66.

Machajewski H., Pietrzak R.

2008 Osada ludności kultury przeworskiej z młodszego i późnego okresu rzymskiego oraz z wczesnej fazy okresu wędrówek ludów na stanowisku 226 (AUT 194), [in:] Poznań-Nowe Miasto. Źródła archeologiczne do studiów nad pradziejami $i$ wczesnym średniowieczem dorzecza środkowej Warty, H. Machajewski, R. 
Pietrzak (eds.), Archeostrada. Studia i materiały z badań wykopaliskowych na autostradzie A2 - odcinek wielkopolski, vol. II, Poznań, p. 363-434.

Maik J.

2012 Wtókiennictwo kultury wielbarskiej, Łódź.

Makowiecki D.

2003 Historia ryb $i$ rybołówstwa $w$ holocenie na Nizu Polskim $w$ świetle badań archeoichtiologicznych, Poznań.

Mårtensson L., Nosch M.-L., Andersson Strand E.

2009 Shape of things: understanding a loom weight, Oxford Journal of Archaeology 28/4, p. 373-398.

Meyer E.

1971 Die germanische Bodenfunde der spätrömischen Kaiserzeit und der frühen Völkerwanderungszeit in Sachsen, I, Arbeits- und Forschungsberichte zur Sächsischen Bodendenkmalpflege 9, Berlin.

1976 Die germanische Bodenfunde der spätrömischen Kaiserzeit und der frühen Völkerwanderungszeit in Sachsen, II. Text, Arbeits- und Forschungsberichte zur Sächsischen Bodendenkmalpflege 11, Berlin.

Michałowski A.

2011 Budownictwo kultury przeworskiej, Poznań.

Michałowski A., Sikorski A.

2011 Budynek ziemiankowy w Szymanowicach, pow. Legnica, woj. dolnoślaskie, stan. 1 - obiekt 146E. Uwagi o obiektach z warsztatami tkackimi na osadach ludności kultury przeworskiej, Sborník prací Filozofické fakulty brněnské univerzity. M, Řada archeologická 60/M16, p. 135-151.

Moszyński K.

1967 Kultura ludowa Stowian. Tom I. Kultura materialna, Warszawa.

Nahlik A.

1956 W sprawie rozwoju krosna tkackiego, Kwartalnik Historii Kultury Materialnej IV/3, p. 519-540.

Natuniewicz-Sekuła M., Rein Seehusen Ch.

2010 Baltic connections. Some remarks about studies of boat-graves from the Roman Iron Age. Finds from the Slusegård and Weklice cemeteries, [in:] Worlds Apart? Contacts across the Baltic Sea in the Iron Age. Network Denmark-Poland, 20052008, U. Lund Hansen, A. Bitner-Wróblewska (eds.), Nordiske Fortidsminder, Serie C, vol. 7, København - Warszawa, p. 287-313.

Niedźwiedź J.

1994 Dokumentacja z badań wykopaliskowych na stan. 6 w Gródku nad Bugiem, gm. Hrubieszów, Hrubieszów - archiwum Muzeum im. ks. St. Staszica w Hrubieszowie.

Niedźwiedź J., Panasiewicz W.

1995 Badania na osadzie wielokulturowej $w$ Gródku nad Bugiem stan. 6, [in:] Sprawozdania $z$ badań archeologicznych $w$ województwie zamojskim $w 1994$ roku, A. Urbański (ed.), Zamość, p. 15-18.

Niezabitowska-Wiśniewska B.

2018a Cmentarzysko kultury przeworskiej, [in:] B. Niezabitowska-Wiśniewska, PuławyWtostowice. Wielokulturowe stanowisko z zachodniej Lubelszczyzny, Lublin, p. 408-571.

2018b Materiaty osadowe kultur przeworskiej i wielbarskiej, [in:] B. Niezabitowska- 
Wiśniewska, Puławy-Wtostowice. Wielokulturowe stanowisko $z$ zachodniej Lubelszczyzny, Lublin, p. 600-640.

Ostasz A.

2003 Osada kultury wielbarskiej w Ulkowych gmina Pszczótki, stanowisko 1 (25 na trasie A-1), [in:] XIII sesja pomorzoznawcza, vol. 1. Od epoki kamienia do okresu rzymskiego, M. Fudziński, H. Paner (eds.), Gdańsk, p. 287-301.

Paner H., Fudziński M., Godon K.

2003 Ratownicze badania archeologiczne $w$ obrębie autostrady A1 na terenie województwa pomorskiego w roku 2000, Pomorania Antiqua XIX, p. 7-36.

Parczewski M.

1988 Poczatki kultury wczesnostowiańskiej w Polsce. Krytyka $i$ datowanie źródet archeologicznych, Prace Komisji Archeologicznej 27, Wrocław - Warszawa Kraków - Gdańsk - Łódź.

Pazda S., Konczewska M., Konczewski P.

2007 Osada z późnego okresu wpływów rzymskich w Nowej Wsi, pow. Bolesławiec, na stanowisku 4, [in:] Archeologiczne Zeszyty Autostradowe Instytutu Archeologii i Etnologii PAN, vol. 6, Badania na autostradzie A4, część IV, B. Gediga (ed.), Wrocław, p. 203-260.

Plunkett S.J.

1999 The Anglo-Saxon loom from Pakenham, Suffolk, Proceedings of the Suffolk Institute of Archaeology and History XXXIX/3, p. 277-298.

Podgórska-Czopek J.

1991a Sprawozdanie $z$ badań wykopaliskowych na osadach kultury przeworskiej $w$ Białobrzegach, stanowisko $8 i$ Budach Eańcuckich, stanowisko 5, woj. Rzeszów (badania 1984), Materiały i Sprawozdania Rzeszowskiego Ośrodka Archeologicznego za lata 1980-1984, p. 173-177.

1991b Materiaty z wczesnostowiańskiej osady w Grodzisku Dolnym, stan. 3, woj. Rzeszów, Archaeoslavica 1, p. 9-60.

2006 Wczesnostowiański kompleks osadniczy nad dolnym Wistokiem na przedpolu Karpat, [in:] Wczesne średniowiecze w Karpatach Polskich, J. Gancarski (ed.), Krosno, p. 89-109.

2009 Grodzisko Dolne, stanowisko 22 - wielokulturowe stanowisko nad dolnym Wistokiem. Część II. Okresy rzymski i wczesnosłowiański, Collectio Archaeologica Ressoviensis XII, Rzeszów.

Popek M., Pydyn A., Solecki R., Stencel P.

2013 Przeprawa mostowa na wyspe Wielka Żuława na jeziorze Jeziorak, [in:] Archaeologica Hereditas 02. Grodziska Warmii i Mazur 1. Stan wiedzy $i$ perspektywy badawcze, Z. Kobyliński (ed.), Warszawa - Zielona Góra, p. 373-380.

Przewoźna K.

1965 Osada zI w. p.n.e. / I w. n.e. w Jastarni, pow. Puck, Pomerania Antiqua I, p. 183-212.

Půlpánová-Reszczyńska A., Kadrow S., Bober M.

2017 Wielokulturowe stanowisko $n r 1 \mathrm{w}$ Zamiechowie, powiat jarosławski, Via Archaeologica Ressoviensia XIII, Rzeszów.

Reder J.

2018 Przyrodnicze uwarunkowania lokalizacji wielokulturowego stanowiska pradziejowego w Puławach-Wtostowicach, [in:] B. Niezabitowska-Wiśniewska, Puławy-Wtostowice. Wielokulturowe stanowisko z zachodniej Lubelszczyzny, Lublin, p. 126-141. 
Reszczyńska A.

2014 Nowe materiaty do poznania wtókiennictwa kultury przeworskiej z obszaru potudniowo-wschodniej Polski, Materiały i Sprawozdania Rzeszowskiego Ośrodka Archeologicznego 35, p. 127-140.

Rodzińska-Nowak J.

2012 Gospodarka żywnościowa ludności kultury przeworskiej, Kraków.

Rulewicz M.

1994 Rybołówstwo Gdańska na tle ośrodków miejskich Pomorza od IX do XIII wieku, Prace Komisji Archeologicznej 11. Gdańsk wczesnośredniowieczny X, Wrocław Warszawa - Kraków.

Schmidt B.

1961 Die späte Völkerwanderungszeit in Mitteldeutschland, Veröffentlichungen des Landesmuseums für Vorgeschichte in Halle 18, Halle (Saale).

1970 Die späte Völkerwanderungszeit in Mitteldeutschland. Katalog (Südteil), Veröffentlichungen des Landesmuseums für Vorgeschichte in Halle 25, Berlin.

1976 Die späte Völkerwanderungszeit in Mitteldeutschland. Katalog (Nord- und Ostteil), Veröffentlichungen des Landesmuseums für Vorgeschichte in Halle 29, Berlin.

Schneider J.

1967 Altslawische Siedlungsfunde von Grieben, Kreis Tangerhütte, Jahresschrift für Mitteldeutsche Vorgeschichte 51, p. 305-336.

Schuster J.

2004 Herzsprung. Eine kaiserzeitliche bis völkerwanderungszeitliche Siedlung in der Uckemark, Berliner Archäologische Forschungen 1, Berlin.

2011 Wielbark - Przeworsk - Luboszyce. Z badań nad stosunkami kulturowymi na przełomie II/III w. między środkowa Łabq a Odra, [in:] Nadodrze w starożytności. Konferencja Grabice, 23-30 czerwca 2004 roku, G. Domański (ed.), Zielona Góra, p. 141-161.

2018 Ab Oceano. Ein Beitrag zur Besiedlungsgeschichte der Küste Vorpommerns während der römischen Kaiserzeit, Beiträge zur Ur- und Frühgeschichte Mecklenburg-Vorpommerns 53, Schwerin.

Sikorski A.

2000 Wczesnośredniowieczne grzęzidta z Góry, stan. 18, gm. Pobiedziska, byłe woj. poznańskie, Wielkopolskie Sprawozdania Archeologiczne 5, p. 259-270.

Skowron J.

2010 Obiekty produkcyjne zosad ludności kultury przeworskiej w Polsce środkowej, [in:] Archeológia barbarov 2009. Hospodárstvo Germánov. Sídliskové a ekonomické štruktúry od neskorej doby laténskej po včasný stredovek, Zbornik referátov $z \mathrm{~V}$. protohistoryckej konferencie Nitra, 21-25 septembra 2009, J. Belják, G. Březinova, V. Varsik (eds.), Nitra, p. 419-448.

2016 Relikty warsztatów rzemieślniczych w kulturze przeworskiej. Zarys problematyki, [in:] Viator per devia scientiae itinera. Studia nad problematyka okresów przedrzymskiego, rzymskiego, wędrówek ludów i wczesnego średniowiecza. Professori Thaddeo Makiewicz septuagenario amici et socii, A. Michałowski, M. Teska, M. Żółkiewski (eds.), Poznań, p. 51-70.

Słomska J.

2015 Stów kilka o krośnie pionowym w kulturze przeworskiej, [in:] Barbari Superiores et Inferiores. Archeologia Barbarzyńców 2014. Procesy integracji środkowoeuro- 
pejskiego Barbaricum. Polska - Czechy - Morawy - Stowacja, L. Tyszler, E. Droberjar (eds.), Łódź - Wieluń, p. 451-457.

2019 Loom weights - a general typology of finds from Poland, Przegląd Archeologiczny 67, p. 89-99.

Sobucki A.

2008 Ciężarki płasko-kuliste $z$ Wielkopolski na tle podobnych znalezisk z Europy Środkowej, [in:] Ad Oderam fluvium. Księga dedykowana pamięci Edwarda Dabrowskiego, B. Gruszka (ed.), Zielona Góra, p. 521-528.

Stahlhofen H.

1978 Eine spätbronzezeitliche Webstuhlgrube in Wallwitz, Kr. Burg, Ausgrabungen und Funde 23, p. 179-183.

Stanciu I.

2012 About the use of the so-called clay "breadcakes" in the milieu of the early Slav settlements (6th-7th centuries), Ephemeris Napocensis XXII, p. 253-277.

Stasiak-Cyran M.

1999 Wyniki czwartego sezonu badań na osadzie kultury przeworskiej w Nieszawie Kolonii, stan. 5, pow. Opole Lubelskie, Archeologia Polski Środkowowschodniej IV, p. 123-129.

2004 Czy Wandalowie byli dobrymi myśliwymi i rybakami, [in:] Wandalowie strażnicy bursztynowego szlaku. Katalog wystawy w Państwowym Muzeum Archeologicznym, J. Andrzejowski, A. Kokowski. Ch. Leiber (eds.), Lublin Warszawa, p. 90-96.

2016 Nieszawa Kolonia stanowisko 5, powiat Opole Lubelskie. Interdyscyplinarna monografia osady z okresu rzymskiego, Lublin.

2018 Próba rekonstrukcji modelu diety mieszkańców Lubelszczyzny $w$ pierwszych wiekach naszej ery, [in:] Dziedzictwo kulinarne w kontekstach tradycyjnych $i$ wspótczesnych, J. Adamowski, M. Tymochowicz (eds.), Lublin, p. 43-51.

Strobin A.

2015 Osada kultury oksywskiej $i$ wielbarskiej $w$ Lipiankach, gm. Kwidzyn, stan. 3 (część II - źródta ruchome), [in:] Kontakty ponadregionalne kultury wielbarskiej. Przemiany kulturowe w okresie wptywów rzymskich na Pomorzu, M. Fudziński, H. Paner (eds.), Gdańsk, p. 125-193.

Szałkowska-Łoś J., Łoś J.

2013 Zakrzewska Osada. Cmentarzysko kultury pomorskiej i wielbarskiej na Pojezierzu Krajeńskim, Ocalone Dziedzictwo Archeologiczne 2, Bydgoszcz - Pękowice.

Ulanowska A.

2017 Innovative or Traditional? Diachronic Approach to Weaving Technology in Bronze Age Greece, [in:] Archeologia powszechna. Tradycje i innowacje $w$ technologii włókienniczej w epoce brazu w Europie i basenie Morza Śródziemnego, A. Ulanowska, M. Siennicka (eds.), Światowit LVI, Warszawa, p. 57-73.

2019 Why are some discoid loom weights grooved? Answers from experimental archaeology on the functionality of weaving tools in the Bronze Age Aegean, [in:] Stories told around the fountain. Papers offered to Piotr Bielinski on His 70th Bithday, A. Pieńkowska, D. Szelag, I. Zych (eds.), Warszawa, p. 733-758.

Urbaniak A.

2008 Osada kultury przeworskiej i kultury wczesnostowiańskiej na stanowisku $3 \mathrm{w}$ Złotej, powiat Sandomierz, Monografie Instytutu Archeologii Uniwersytetu Łódzkiego 6, Łódź. 
Walenta K.

2009 Leśno i mikroregion w okresie rzymskim, Chojnice.

Warnke D.

1973 Die Siedlungen auf dem Lütjenberg, [in:] J. Herrmann, Die germanischen und slawischen Siedlungen und das mittelalterliche Dorf von Tornow, Kr. Calau, Schriften zur Ur- und Frühgeschichte 26, Berlin, p. 109-176.

Wielowiejski J.

1960 Przemiany gospodarczo-społeczne ludności południowej Polski $w$ okresie późnolateńskim i rzymskim, Materiały Starożytne VI, Warszawa.

Wołąiewicz R.

1960 Osada i grób z okresu rzymskiego w Cedyni nad Odra, Materiały Zachodniopomorskie VI, p. 97-158.

Wyrwa A.M.

2012 Symbolika ryby i miejsce ryb $w$ diecie klasztornej. Zarys problemu, [in:] Ryby $w$ kulturze $i$ rekultywacja środowiska wodnego. Szkic historyczny $i$ badania hydrobiologiczne, A.M. Wyrwa (ed.), Bydgoszcz, p. 9-48.

Zamościński K.

2014 Narzędzia $i$ sprzęty rybackie oraz metody połowu $w$ kaszubskim rybołówstwie jeziornym, [in:] Jem jô rëbôk... Rybotówstwo na Kaszubach - tradycja i

Zbierski A. wspótczesność, A. Kwaśniewska (ed.), Wieżyca, p. 111-256.

1959 Wczesnośredniowieczne materiały archeologiczne z Czermna nad Huczwa (zabytki ruchome z wyjatkiem ceramiki), Archeologia Polski 4/1-2, p. 105-148.

Zimmermann W.H.

1982 Archäologische Befunde frühmittelalterlicher Webhäuser. Ein Beitrag zum Gewichtswebstuhl, Jahrbuch der Männer vom Morgenstern 61, p. 111-144.

1988 Frühe Darstellungen vom Gewichtswebstuhl auf Felszeichnungen in der Valcamonica, Lombardei, Arkeologiske Skrifter 2, p. 26-38.

Znamierowska-Prüfferowa M.

1932 Przyczynek do rybołówstwa na Bugu. Przykład wędrówki wytworu kulturowego, Ziemia 11, p. 263-267.

1933 Rybołówstwo w okolicach Druskiennik, Lud. Organ Polskiego Towarzystwa Ludoznawczego we Lwowie, seria II, t. XII, zeszyt I-IV, p. 21-35.

1957 Rybackie narzędzia kolne $w$ Polsce i $w$ krajach sqsiednich, Toruń.

1988 Tradycyjne rybotówstwo ludowe $w$ Polsce na tle zbiorów $i$ badań terenowych Muzeum Etnograficznego w Toruniu, Torun.

Żychlińska J.

2016 Kilka uwag o warsztatach tkackich ludności kultury tużyckiej, Materiały Zachodniopomorskie, Nowa Seria XII, p 133-148.

Żychliński D.

2008 Giecz i Cieśle - osady ludności kultury przeworskiej z okresu wędrówek ludów w Wielkopolsce, [in:] Barbarská sídliště. Chronologické aspekty jejich vývoje ve světle nových archeologických výzkumů, E. Drobrejar, B. Komoróczy, D. Vachůtová, D. (eds.), Brno, p. 345-388.

2011 Płaskokuliste ciężarki tkackie z osady w Cieślach, pow. poznański, woj. wielkopolskie, [in:] Nadodrze w starożytności. Konferencja Grabice, 23-30 czerwca 2004 roku, G. Domański (ed.), Zielona Góra, p. 163-169. 
Address of the Author

\section{Barbara Niezabitowska-Wiśniewska}

Institute of Archaeology

Maria Curie-Skłodowska University

in Lublin

Plac Marii Curie-Skłodowskiej 4

20-031 Lublin, Poland

barbara.niezabitowska-wisniewska@poczta.umcs.lublin.pl;

baica@poczta.onet.pl

ORCID ID: 0000-0001-7557-4488 
